\title{
An integrated techno-economic and life cycle environmental assessment of power-to-gas systems
}

\author{
David Parra $^{\mathrm{a} 1}$, Xiaojin Zhang ${ }^{\mathrm{b} 1}$, Christian Bauer $^{\mathrm{b}}$, Martin K. Patel ${ }^{\mathrm{a}}$ \\ ${ }^{a}$ Energy Efficiency Group, Institute for Environmental Sciences and Forel Institute, University of Geneva, \\ Boulevard Carl-Vogt 66, 1205 Genève, Switzerland \\ ${ }^{\mathrm{b}}$ Technology Assessment Group, Paul Scherrer Institut, Villigen PSI, Switzerland
}

\begin{abstract}
Interest in power-to-gas (P2G) as an energy storage technology is increasing, since it allows to utilise the existing natural gas infrastructure as storage medium, which reduces capital investments and facilitates its deployment. P2G systems using renewable electricity can also substitute for fossil fuels used for heating and transport. In this study, both techno-economic and life cycle assessment (LCA) are applied to determine key performance indicators for P2G systems generating hydrogen or methane (synthetic natural gas - SNG) as main products. The proposed scenarios assume that P2G systems participate in the Swiss wholesale electricity market and include several value-adding services in addition to the generation of low fossil-carbon gas.
\end{abstract}

We find that none of the systems can compete economically with conventional gas production systems when only selling hydrogen and SNG. For P2G systems producing hydrogen, four other services such as heat and oxygen supply are needed to ensure the economic viability of a $1 \mathrm{MW} \mathrm{P2H}$ system. $\mathrm{CO}_{2}$ captured from the air adds $\$ 50 / \mathrm{MWh}_{\mathrm{t}}$ of extra levelised cost to SNG compared to $\mathrm{CO}_{2}$ supplied from biogas upgrading plants and it does not offer an economic case yet regardless of the number of services. As for environmental performance, only the input of "clean" renewable electricity to electrolysis result in environmental benefits for P2G compared to conventional gas production. In particular, more than $90 \%$ of the life cycle environmental burdens are dominated by the electricity supply to electrolysis for hydrogen production, and the source of $\mathrm{CO}_{2}$ in case of SNG.

Keywords: Renewable Energy; Energy Storage; Power-to-gas; PEM electrolyser; techno-economic analysis; LCA.

\section{Introduction}

In order to cut greenhouse gas (GHG) emissions, the power sector needs to be decarbonised. With substantial expansion of wind and solar photovoltaic (PV) power generation, there is a growing need for new technology which facilitates the integration of such stochastic renewable energy (RE) technologies in the energy system [1]. Among all the possible strategies such as grid expansion, curtailment and demand side management, energy storage (ES) is gaining much attention since it is an option which can: play a role of both energy generator and consumer [2]; be used for different time scales (e.g., short, mid

\footnotetext{
${ }^{1}:$ These authors are the first co-authors that contributed equally to this work.
} 
and long-term ES) [3]; be installed at different scales (e.g., distributed (kW) versus bulk ES (MW)) [4]. For large-scale storage, technologies such as pumped hydro storage and compressed air storage which storage capacities are independent from power ratings are considered $[5,6]$. However, both technologies are highly dependent on local conditions. P2G is more flexible in this regard since it only requires access to the natural gas network or any other gas storage, while supporting a more integrated energy system connecting electricity and gas networks [7]. It can make use of excess RE and/or low-cost electricity, transforms it into gas while leveraging the existing natural gas network [8]. Moreover, P2G can provide ES capacity from minutes to months [9], with the largest plant so far reaching $6 \mathrm{MW}$ (defined by electrical power input) [10]. Larger systems are expected to be deployed given the modularity of different components comprising a P2G system [6].

The first step of a P2G process is splitting water into hydrogen and oxygen by electrolysis. Hydrogen can then be injected into the natural gas network up to a maximum volumetric limit depending on countryspecific regulations [11], or it can meet any hydrogen demands (e.g., transport with refuelling stations). Such a system is known as power-to-hydrogen $(\mathrm{P} 2 \mathrm{H})$ system. Or alternatively, the generated hydrogen can further react with $\mathrm{CO}_{2}$ to form SNG. These systems are referred to as power-to-methane (P2M) systems. $\mathrm{CO}_{2}$ used for methanation can be obtained from various sources but certain contaminants and water need to be removed before it can be fed into methanation to avoid catalyst poisoning [12]. Once SNG is produced from methanation, it can be injected into the natural gas network or it can be directly consumed as a fuel $[6,13]$.

\subsection{Previous techno-economic studies on P2G}

Some implications of different technological options within a P2G system (e.g., electrolyser technology or source of $\mathrm{CO}_{2}$ ), different products and services provided (e.g., gas for mobility, gas being injected to the natural gas network, etc.) in a given regulatory context have been part of the previous P2G technology assessment. Felgenhauer et al. analysed the economic feasibility of $\mathrm{P} 2 \mathrm{H}$ with alkaline and PEM electrolysers for mobility [14], and they found that hydrogen could be competitively supplied by on-site alkaline electrolysers at costs ranging from $\$ 4.96-5.78 / \mathrm{kg}^{2}$ (in particular with capacities above 25 $\mathrm{kg} / \mathrm{h}$ ), in comparison with liquid hydrogen delivered from a central steam methane reforming plant with a cost ranging from $\$ 5-8 / \mathrm{kg}$. A report commissioned by the "European Union Fuel cells and Hydrogen Joint Undertaking" evaluated the cost of $\mathrm{P} 2 \mathrm{H}$ for three different services (small systems for transport applications, medium systems for industrial applications and large systems for energy storage applications) under the regulatory context of five different European countries [15]. Among these three different applications, small $\mathrm{P} 2 \mathrm{H}$ systems (up to $20 \mathrm{MW}$ ) for transport applications was found to be the best economic case, with cost of $\$ 4.8 / \mathrm{kg}$ for a $5 \mathrm{MW}$ system generating $2000 \mathrm{~kg} \mathrm{H}_{2}$ per day for vehicle in an hypothetic German scenario in 2030.

Cost, value and/or profitability have been selected as key performance indicators (KPI) in previous techno-economic analyses evaluating ES under different regulatory contexts [16], among which the latter KPI was less assessed for P2G systems so far. For example, Schiebahn et al. quantified the levelised cost for hydrogen as fuel for transportation, and for hydrogen and methane to be injected into the

\footnotetext{
${ }^{2}$ Conversion rates of 1.07 and 1.00 are used between CHF/EUR, and CHF/USD respectively.
} 
natural gas network in Germany [17]. Likewise, the levelised cost and value have also been analysed for grid injection in Switzerland [6] and six different European countries [15].

\subsection{Previous environmental studies on P2G}

Limited number of studies have addressed the environmental performance of P2G systems. Bhandari et al. reviewed 21 LCA studies of hydrogen production technologies with a focus on hydrogen production via electrolysis [18]. They concluded that the impact on climate change is most frequently quantified, followed by acidification potential, while the other impacts are often not addressed. They also identified electricity supply to have a dominant impact on the results, and found that electrolysis with renewable energy sources is beneficial to reduce the life cycle GHG emissions. The global warming potential of hydrogen produced by grid electricity supply to electrolysis in Germany can be up to 30 times higher than the production with wind energy, due to the $54 \%$ share of fossil fuels in the German grid electricity supply. By comparing P2G with conventional hydrogen and methane production technologies, Reiter et al. found the break-even point for the GHG emissions of electricity supply, so that P2G systems could be competitive with conventional gas production: $190 \mathrm{~g}$ of $\mathrm{CO}_{2}$ equivalents per $\mathrm{kWh}$ for $\mathrm{P} 2 \mathrm{H}$, and $113 \mathrm{~g}$ of $\mathrm{CO}_{2}$ equivalents per $\mathrm{kWh}$ for $\mathrm{P} 2 \mathrm{M}$ if $\mathrm{CO}_{2}$ is considered as a waste product, or $73 \mathrm{~g}$ of $\mathrm{CO}_{2}$ equivalents per $\mathrm{kWh}$ if separation of $\mathrm{CO}_{2}$ is accounted for [19]. In another study, they evaluated different sources of carbon dioxide in Austria, including power plants and industrial processes, with different capturing technologies, thereby accounting for the additional energy consumption and the associated GHG emissions [12]. It was concluded that biogas upgrading facilities and bioethanol plants are the best suited sources of $\mathrm{CO}_{2}$ for Austria. The quantity of $\mathrm{CO}_{2}$ produced from fermentation in bioethanol plants is large and no additional energy is required for capture or purification while for biogas upgrading, $\mathrm{CO}_{2}$ was considered as a waste product without requiring additional energy.

\subsection{Research gaps from previous literature}

Three key research gaps have been identified within the previous literature on P2G systems. Firstly, there are no comprehensive methodologies and studies consistently covering the techno-economic and environmental performance of different P2G systems. Secondly, previous techno-economic and environmental analyses were static, i.e. assuming KPIs such as efficiency of P2G systems and their durability as constant input data regardless of the type of electricity supply and capacity factor. However, this is a strong limitation since these technological parameters are dynamic and they influence the techno-economic and environmental performance substantially. Finally, previous environmental studies have mostly focused on climate change without reporting other environmental impacts. Given these limitations, we present an integrated assessment methodology covering both life cycle technoeconomic and environmental assessment, including electrolyser's ageing and electricity price variations throughout the life of the project. The techno-economic and environmental implications of the system scale, the type of product gas ( $\mathrm{P} 2 \mathrm{H}$ versus P2M) as well as the type and amount of additional services provided are analysed for $\mathrm{P} 2 \mathrm{G}$ with this methodology. 


\section{Methodology}

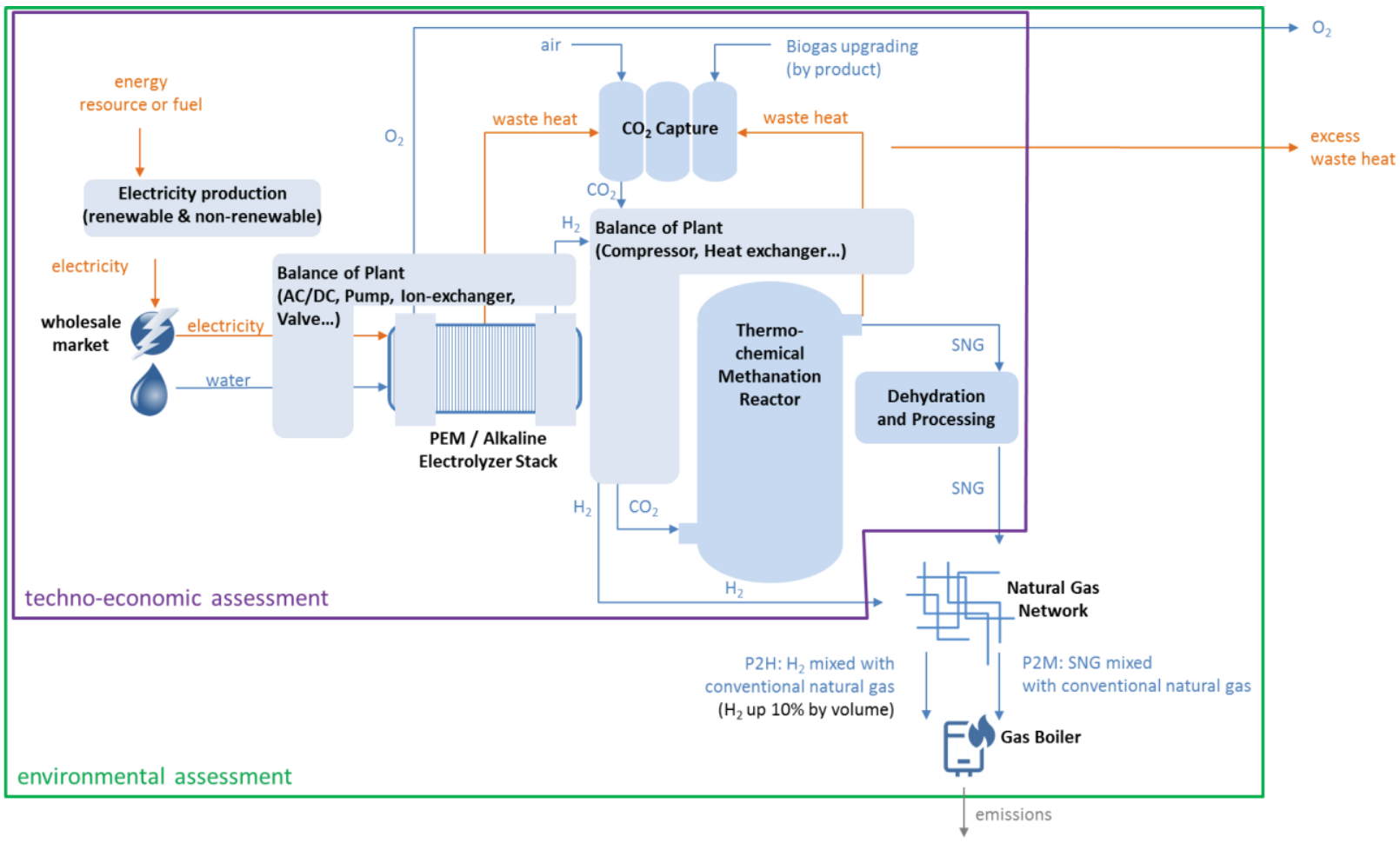

Fig. 1. Schematic of a P2G system including system variations and main components modelled in this study. Note that the system boundary for environmental assessment is slightly different from techno-economic assessment: gas consumption (combustion) is included in environmental assessment in order to consider the full carbon cycle of the system, whereas for techno-economic assessment, the system boundary is at the point of gas production.

Fig. 1 shows a schematic representation of P2G system including its main components analysed in this study. It is assumed that electricity is supplied by the Swiss wholesale electricity market and therefore, no direct connection to a particular RE plant (e.g., PV or wind systems) is considered. For the operation in the wholesale market and in agreement with previous studies for P2G [20] and other ES technologies $[21,22]$, it is assumed that P2G plants run at full capacity, i.e. steady state operations in order to make as much profit as possible when prices are low enough to minimise the levelised cost .The produced hydrogen or SNG from the P2G system are injected into the natural gas network and sold to the Swiss wholesale natural gas market, but with a higher value than conventional natural gas, the premium being proportional to the renewable electricity supply. We compare $\mathrm{CO}_{2}$ supply from direct atmospheric capture and biogas upgrading plants considering that Switzerland does not have fossil power plants. The first source entails a promising technology which location is independent of fossil generation plants and industries releasing $\mathrm{CO}_{2}$ to the atmosphere (e.g., cement); and it is attracting the attention of the Swiss industry. The supply of $\mathrm{CO}_{2}$ from biogas plants is a win-win situation since it avoids the cost of biogas upgrading. Therefore, the latter supply is not explicitly included in the model because they are anyway required in existing biogas plants in order to ensure compliance with the required biogas specifications. Therefore, $\mathrm{CO}_{2}$ from biogas upgrading is assumed to be supplied free of charge and environmental burdens (i.e., considered as a waste) [6]. The reader is suggested to check the work by P. Collet et al. for a detailed analysed of the various biogas upgrading steps for P2G technologies [23]. 
The system represented in Fig. 1 is simulated and analysed for several system scales based on the electrolyser nominal rating, namely $25 \mathrm{~kW}, 100 \mathrm{~kW}, 1 \mathrm{MW}, 10 \mathrm{MW}, 100 \mathrm{MW}$ and $1000 \mathrm{MW}$. The dependency with the system scale was already considered in a previous study but only from a technoeconomic perspective. Furthermore, the technical model utilised for this study was refined according to some criteria such as the consideration of electricity imports from neighbour countries; the comparison of capture from the atmosphere and biogas upgrading as $\mathrm{CO}_{2}$ sources; the limitation of heat supply to half of the year therefore acknowledging the heating season; and the reduction of the efficiency of the methanation reactor to $80 \%$. Although systems of hundreds and thousands $\mathrm{MW}$ have not been realised yet, the P2G equipment is not the limiting factor since it could be applied on a modular basis. The assessment is based on a time-dependent model with 1-hour resolution (based on the temporal resolution of the electricity wholesale market). A bottom-up model was utilised to model the various components (including the polarisation curve of the cell stack) using empirical data from electrolyser systems already installed in Europe to determine the rating of the balance-of-plant (BoP) up to the 1 MW scale. In the case of systems with larger capacity, it was assumed that the electrolyser's BoP rating increases linearly with the capacity taking a $1 \mathrm{MW}$ system as a reference since electrolyser systems with larger capacities consist of several stacks in parallel due to cell area constraints [15]. A more detailed description of the technical model can be found in Supplementary Information (SI) under section 7.1.

Various KPI are determined using a life-cycle approach, i.e. the data of the hourly model (e.g., electricity consumption and gas production) are aggregated and discounted when necessary over the system's lifetime while accounting for degradation of electrolyser and dynamics of electricity prices. In particular, the lifetime of the PEM stack was utilised to specify the life cycle and therefore, a residual value was given to the different BoP using linear depreciation since they have a longer lifetime. PEM technology was selected as electrolysis in this study due to its advantages over more traditional alkaline technology, namely higher efficiency and power density, suitability for dynamic operation, high pressure operation (up to 60 bar) as well as current commercial availability [24, 25]. Besides, alkaline has already been more discussed in the literature given its higher maturity and lower cost, around $\$ 500 / \mathrm{kW}$ for the stack [6].

\subsection{Economic assessment methodology and input data}

Assuming that P2G systems purchase electricity from and sell gas to the wholesale market, the intrinsic benefit created by a P2G system, Ben $(\$)$, is driven by the difference between the price at which the gas is sold on the wholesale market $P_{g w}(\$ / M W h)$, and the price of consumed electricity, $P_{e w}(\$ / M W h)$, as indicated by Eq. (1); $E_{e}(M W h)$ and $E_{g}\left(M W h_{t}\right)$ refer to the total electricity consumption and the gas production respectively of the P2G system while the subindex $t$ refers to the thermal content of the produced gas. The higher heating value (141.8 MJ/kg for hydrogen and $55.5 \mathrm{MJ} / \mathrm{kg}$ for SNG) was used for this purpose. Electricity price provided by the Swiss wholesale electricity market including imports from neighbour countries [26] together with natural gas spot prices reported in Europe in 2014 [26] were used as input data in this study. Wholesale electricity prices with $1 \mathrm{hr}$ resolution were used given the strong fluctuations within the same day, but a constant price throughout the year (equal to $\$ 31 / \mathrm{MWh}_{\mathrm{t}}$ in 2014, see SI Fig. 4) was assumed for gas since price variations occur on a long-term scale (several weeks or months). Likewise, annual energy price variations were included in the model since a P2G system is an investment which lasts for several years. For the electricity prices, the estimates of the 
European Energy Exchange were assumed, according to which wholesale electricity prices will remain constant until 2020 [26], while results from the Swissmod model (deterministic and assuming a perfectly competitive market) [27] were utilised in this study for 2020 onwards. For the wholesale natural gas price evolution, data from the Swiss energy strategy were utilised [28].

$$
B e n_{g}=E_{g} \times P_{g w}-E_{e} \times P_{e w}
$$

The gas produced by a P2G system with a certain amount of RE for electrolysis is assumed to have a higher value, Price ${ }_{22 \text { ggas }}(\$ / M W h)$, than conventional natural gas, Price $_{C_{4} 4}$ (equal to $\$ 31 / \mathrm{MWh}_{\mathrm{t}}$ in 2014 ) due to its partially renewable energy content [6]. For example, 100\% biogas in Switzerland was sold at $\$ 90 / \mathrm{MWh}_{\mathrm{t}}$ in 2014 corresponding to a premium (Price premium-biogas) of $\$ 60 / \mathrm{MWh}_{\mathrm{t}}$ for a $100 \% \mathrm{RE}$ supply. The gas produced by a P2G system is assumed to incorporate this additional value, with a correction to account for the non-renewable energy share in the Swiss electricity mix including imports, $\mathrm{RE}_{\text {Swissmix, }}$ according to the electricity supply from neighbour countries, namely Germany, France, Austria and Italy. According to this approach, the P2G gas generated by a $100 \%$ RE supply has the same value as $100 \%$ biogas. The total amount of imports as well as the electricity supply mix by country were given by the Swissmod model while we assumed that the fractions of imports per country will stay constant over time as a first estimation. The value of the gas produced by a P2G system as a function of the RE electricity supply was calculated using Eq. (2) for every year that the P2G system is in operation. Fig. 2 provides the value of the gas produced by a P2G system with Swiss electricity supply with and without imports as well as the corresponding RE share in the supply mix up to 2025. The reader can also find the wholesale electricity, natural gas and biogas prices utilised as input data. 
Fig. 2. Value of the gas produced by P2G systems based on the RE content of the Swiss electricity supply with and without imports from neighbour countries; and RE share of the Swiss supply with and without imports. The figure also shows the average wholesale price for electricity and the prices for biogas and conventional natural gas as references since they are limiting cases, i.e. $100 \%$ and $0 \% \mathrm{RE}$, content respectively.

$$
\text { Price }_{\mathrm{P} 2 \mathrm{Ggas}}=\text { Price }_{\mathrm{CH} 4}+\text { Price }_{\text {premium-biogas }} \times R E_{\text {Swissmix }}
$$

As suggested by Fig. 1, several co-products are generated during normal P2G operation in addition to gas. The baseline scenario includes the benefits from providing: a) heat supply to a district heating system; b) oxygen sold to industry c) frequency control in the primary reserve market (electricity grid stability); and d) the avoided cost for the production and import of fossil fuel ( $\mathrm{CO}_{2}$ levy) in Switzerland. Heat is generated by both the electrolyser and methanation reactor at the temperatures given in Table 2 and the final heat supply temperature (which depends on the final balance between them) may not be suitable for all district heating schemes in particular those which are less efficient (temperatures higher than $100{ }^{\circ} \mathrm{C}$ ). For $\mathrm{CO}_{2}$ capture from the atmosphere, the latter is assumed to be used internally as heat source for $\mathrm{CO}_{2}$ capture from the atmosphere. Furthermore, it was assumed that heat can only be sold during half of the year as a first attempt to model the heating season. The calculations for the frequency control are based on the methodology presented by Hofstetter et al. for primary control in Switzerland [6]. Table 1 includes the main assumptions for any of the services included the P2G value proposition analysis together with typical values given by manufactures and found in the previous literature. 
Table 1: Main assumptions and related input data considered for the different applications included in the baseline scenario using the Swiss regulatory context. Other values from the previous literature are also included for comparison purposes.

\begin{tabular}{|c|c|c|}
\hline P2G application & Values in the literature & Selected value for Switzerland \\
\hline $\begin{array}{l}\text { Renewable premium for } \\
100 \% \text { RE supply }\end{array}$ & $\$ 40-79 / \mathrm{MWh}_{\mathrm{t}}$ (Germany [6]) & $\$ 60 / \mathrm{MWh}_{\mathrm{t}}$ \\
\hline Heat supply & $>\$ 37 / \mathrm{MWh}_{\mathrm{t}}$ (Sweden [29]) & $\$ 60 / \mathrm{MWh}_{\mathrm{t}}$ \\
\hline Oxygen Supply & $\$ 0.02-0.19 /$ kg (Germany [6]) & $0.1 \$ / \mathrm{kg}$ \\
\hline Frequency control & $\begin{array}{l}22349 \text { and } 46895 € / M W \cdot y e a r \\
\text { for minutes reserve and } \\
\text { secondary control (Germany ) }\end{array}$ & $\begin{array}{l}\text { Swiss primary market } \\
(\$ 210000 / \mathrm{MW} \cdot \text { year })\end{array}$ \\
\hline $\mathrm{CO}_{2}$ levy & $\begin{array}{c}\$ 107 / \text { ton } \mathrm{CO}_{2}(2030 \text { value in } \\
\text { Europe [20]) }\end{array}$ & $\begin{array}{l}\$ 60 / \text { ton } \mathrm{CO}_{2} \text { equal to } \$ 14 / \mathrm{MWh}_{\mathrm{t}} \text { for } \\
100 \% \text { RE supply }\end{array}$ \\
\hline
\end{tabular}

We determine three complementary techno-economic KPIs, namely the levelised cost, the levelised value and the profitability. The levelised cost has been widely utilised as a measure of the overall competitiveness of different generating technologies and the concept has been extended to ES more recently. The levelised cost of ES, LCOES $\left(\$ / M W h_{t}\right)$, represents the present cost associated with the gas production of a P2G system throughout the life accounting for round trip efficiency, degradation and capacity factor of the plant. It is calculated using Eq. (3) including the capital expenditure, CAPEX (\$), and operational expenditure, OPEX (\$), of the P2G plant; $r(\%)$ is the discount factor accounting for the time value of money, the inflation and the risk associated with the P2G investment [30]. A value of $8 \%$ was assumed in this study in agreement with other previous analysis on P2G $[6,15]$. Both the OPEX and the gas production are accounted on an annual basis indicated as $y$ in Eq. (3) where $n$ is the number of years the electrolyser stack lasts for. The CAPEX of a P2G system was broken down as electrolyser system's cost (including cell stack, BoP and power converter), methanation reactor in case of P2M (including reactor and BOP) and general BoP while the OPEX was broken down as cost of the electricity purchased for running the plant, grid charges for being connected to the electricity network, operational cost of $\mathrm{CO}_{2}$ source and maintenance of the different equipment represented in Fig. 1 . The total cost for $\mathrm{CO}_{2}$ captured from air was assumed to be $\$ 200 /$ ton which is the target cost according to a Swiss manufacturer [31]. Although economies of scale may apply for this technology, the $\mathrm{CO}_{2}$ capture cost was assumed to be linear with the scale given the lack of related details. This $\mathrm{CO}_{2}$ capture cost is further divided into CAPEX and OPEX, with the latter given by the electricity and heat consumption. In particular, an OPEX of $\$ 10 /$ ton was determined based on the average electricity consumption of the equipment ( $250 \mathrm{kWh} /$ ton of $\left.\mathrm{CO}_{2}[32]\right)$ and the wholesale electricity price. The heat requirements of the capturing unit, equal to $1500 \mathrm{kWh} /$ ton of $\mathrm{CO}_{2}$, were assumed to be provided internally by the methanation reactor. The remaining specific cost $(\$ 190 /$ ton) corresponds to the CAPEX and this was then multiplied by the total amount of $\mathrm{CO}_{2}$ capture (ton) required by the system during a lifetime of 10 years. The relevant input cost data is given in Table 2.

$$
L C O E S=\frac{C A P E X+\sum_{y=1}^{n} \frac{O P E X}{(1+r)^{y}}}{\sum_{y=1}^{n} \frac{E g_{y}}{(1+r)^{y}}}
$$


Table 2: Values selected for the different technical parameters of P2G plants in the baseline scenario together with those selected in the previous literature.

\begin{tabular}{|c|c|c|}
\hline Parameter (unit) & Values in the literature & Selected value \\
\hline Nominal electrolyser temperature $\left({ }^{\circ} \mathrm{C}\right)$ & $50-80[3]$ & 80 \\
\hline Nominal electrolyser pressure (bar) & Up to $70[3]$ & 15 \\
\hline Maximum current density $\left(\mathrm{A} / \mathrm{cm}^{2}\right)$ & $10-20[33]$ & 20 \\
\hline Nominal cell specific consumption $\left(\mathrm{W} / \mathrm{cm}^{2}\right)$ & $<4.4[34]$ & $3.9^{3}$ \\
\hline Lifetime stack (h) & $<60000[35]$ & 50000 \\
\hline Degradation rate $(\mu \mathrm{V} / \mathrm{h})$ & Up to 15 [34] & 5 \\
\hline Methanation reactor efficiency (\%) & $70-85[35,36]$ & 80 \\
\hline Methanation reactor temperature $\left({ }^{\circ} \mathrm{C}\right)$ & $250-500[6]$ & n.a. \\
\hline Electrolyser stack cost $\left(\$ / \mathrm{kW}_{\mathrm{e}}\right)$ & $900-1300$ & 1000 \\
\hline Electrolyser's BoP cost $\left(\$ / \mathrm{kW}_{\mathrm{e}}\right)$ & $750-1400[6]$ & 1090 \\
\hline Compression system $\left(\$ / \mathrm{kW}_{\mathrm{e}}\right)$ & $100-150[6,37]$ & 134 \\
\hline Methanation reactor cost $\left(\$ / \mathrm{kW}_{\mathrm{t}}\right)$ & $100-500[6,37]$ & 145 \\
\hline Methanation reactor's BoP cost $\left(\$ / \mathrm{kW}_{\mathrm{t}}\right)$ & $250-450[6]$ & 340 \\
\hline General BoP cost $\left(\$ / \mathrm{kW}_{\mathrm{e}}\right)$ & $-+30 \%$ & 300 \\
\hline Electrolyser O\&M cost (\% CAPEX) & 1.5-4.5 [20] & 2 \\
\hline Methanation O\&M cost (\% CAPEX) & $5-7.5[6,20]$ & 5 \\
\hline BoP O\&M cost $\left(\%\right.$ CAPEX) ${ }^{h}$ & $6-7[6,20]$ & 7 \\
\hline Total $\mathrm{CO}_{2}$ capturing cost from air (\$/ton) & n.a. ${ }^{4}$ & 200 \\
\hline
\end{tabular}

Economies of scale were assumed for the CAPEX for the electrolyser system, methanation reactor and BoP in agreement with other large chemical conversion processes [6, 38]. In particular, a power function with a factor $p$ equal to 0.7 was used for this model purpose, defined in Eq. (4). For example, the economies of scale for a $10 \mathrm{MW}$ electrolyser stack referred to as Scale (kW) were determined with regard to a threshold scale, $S c a l e_{l}(\mathrm{~kW})$, which was assumed to be $25 \mathrm{~kW}$ in this study. Then, $\operatorname{cost}_{r}(\$ / \mathrm{kW})$ refers to the relative cost shown in Table 2, i.e. $\$ 1000 / \mathrm{kW}$ for the PEM stack. The maximum scale included in this study (i.e. $1 \mathrm{GW}$ which is not yet available in the market) is however larger than typical large scale chemical conversion processes were economies of scale are typically observed.

$$
\operatorname{Cost}_{\text {comp }}=\left(\frac{\text { Scale }_{\text {scale }}}{\text { sca }^{p}} \times \text { Scale }_{l} \times \text { cost }_{r}\right.
$$

In line with the levelised cost concept, the levelised value, LVOES $\left(\$ / M W h_{t}\right)$, representing the annualised total revenue, $B_{P 2 G}(\$)$, accrued by a P2G system with regard to the gas production is determined using Eq. (5). As discussed in Section 2, a P2G system could also benefit from providing co-products and services (see Table 1 ) to their corresponding markets if the existing regulation allows. Therefore, Ben $n_{P 2 G}$ (\$) represents the various benefits, i.e. low fossil-carbon gas supply with renewable premium

\footnotetext{
${ }^{3}$ Resulted from the PEM electrolyser model

${ }^{4}$ Benchmark cost data for this novel technology correspond to cost of other alternative $\mathrm{CO}_{2}$ sources such as fossil plants and industry.
} 
(proportional to the renewable content of the electricity supply to the electrolyser), heat supply to a district heat system, oxygen supply, frequency control in the primary reserve market and avoided $\mathrm{CO}_{2}$ levy in Switzerland. Finally, the internal rate of return, IRR (\%), is defined in Eq. (6) as the discount rate which balances the different annualised cash flows (both expenses and revenues), $C F_{y}(\$)$, associated with the P2G plant, CF (\$). Therefore, the P2G system creates value when positive IRR values are achieved, but only when the IRR is higher than the assumed discount factor ( $8 \%$ ), the P2G project should be selected from a purely financial perspective. The results presented in this study are an indication of the upper potential profitability since no additional cost for connection to the district heat system, oxygen storage, etc. were considered with these services.

$$
\begin{aligned}
& \text { LVOES }=\frac{\sum_{y=1}^{n} \frac{B e n_{P 2 G_{y}}}{(1+r) y}}{\sum_{y=1}^{n} \frac{E_{y}}{(1+r)^{y}}} \\
& 0=\sum_{y=0}^{n} \frac{C F_{y}}{(1+I R R)^{y}}
\end{aligned}
$$

Given the assumed operation of P2G systems in the wholesale electricity market (contrary to the direct coupling with a RE generator), an operational strategy should be included in order to schedule the operation of the electrolyser. An optimisation method which minimises the levelised cost of the P2G system previously presented by Parra et al. was also used in this study [39]. This method allows to determine the optimum price signal (i.e. maximum set price of electricity for the electrolyser to run) for each P2G scale (electrolyser rating) depending on the evolution of electricity prices and the electrolyser efficiency throughout the life of the electrolyser. For example, the optimum price signal for a $1 \mathrm{MW}$ P2G system performing was equal to $\$ 46 / \mathrm{MWh}_{\mathrm{e}}$ achieving a capacity factor of $62 \%$ in 2016 , but it was adapted according to the electricity price evolution (e.g., $\$ 49 / \mathrm{MWh}_{\mathrm{e}}$ by 2025 ).

\subsection{Environmental assessment methodology and inventory data}

Life Cycle Assessment (LCA) is a widely applied methodology for comprehensive environmental assessment of products and services. It quantifies the potential environmental impacts from raw material acquisition to end-of-life disposal throughout a product's life cycle, which highlights environmental hot-spots and helps to identify the potential opportunities to improve the environmental performance of the product. In this study, process-based attributional LCA is performed according to ISO 14040 [40]. Simapro [41] is used as analysis software, and the ecoinvent database version 3.1 [42] is used as the background $\mathrm{LCI}^{5}$ database [43].

The LCA analysis includes electricity production, electrolysis, two $\mathrm{CO}_{2}$ sources $\left(\mathrm{CO}_{2}\right.$ captured from atmosphere or from biogas upgrade), methanation, product gas processing, and application of gas as fuel in gas boiler to produce heat (see Fig. 1). The LCl data is partly based on [44], and partly adjusted to take into account the modelling results obtained from the technical model of P2G in this work, such as

\footnotetext{
${ }^{5} \mathrm{LCl}$ processes used in an LCA can be separated into foreground and background processes. The foreground data represent the processes of the system under investigation itself, i.e. selected activities that reflect the immediate space for action; these are collected for the purpose of the specific LCA. Background data are more generic data used for modelling the remaining activities.
} 

and allocated to each unit of gas production based on the lifetime production of the system, except the energy consumption of facility construction and catalyst manufacturing for the methanation unit, due to limited data availability. The functional unit is defined as $1 \mathrm{MWh}_{\mathrm{t}}$ of combustion heat generated from the gas boiler, which is estimated based on the higher heating value of product gases (mixture of hydrogen from $\mathrm{P} 2 \mathrm{H}$ and conventional natural gas, or SNG from P2M, or conventional natural gas in the baseline case).

Ecoinvent database version 3.1 is used to as the background database $[45,46]$ for electricity supplies, with technology shares derived from the results of Swissmod model [27] from 2015 to 2025 (SI Table 2). Allocation of environmental burdens based on products' levelised value (as shown in Fig. 6 for $\mathrm{P} 2 \mathrm{H}$ ) is performed. The allocation factors calculated for hydrogen, oxygen and heat are $70 \%, 19 \%, 11 \%$ respectively, in which the allocation factor for hydrogen is calculated based on the levelised value of gas with premium. In $\mathrm{P} 2 \mathrm{H}$, the hydrogen produced is assumed to be blended with conventional natural gas in the gas network at a volumetric percentage of $10 \%$, as it saves the investment on dedicated hydroegn storage by utilising the existing network, and $10 \%$ is on average relatively low concentration of hydrogen allowed in gas network, that appears to be viable without significantly increasing the risks associated with consuming the blended gas in end-use devices [47]. It is assumed the gas is well-blended before it is consumed, and the dynamic blending and distribution of gas is outside of the scope of this study. Blending $10 \%$ of hydrogen with natural gas by volume will reduce the $\mathrm{CO}_{2}$ emission per $\mathrm{MJ}$ of heat generation by $9.8 \%$, due to lower density of $0.725 \mathrm{~kg} / \mathrm{Nm}^{3}$ (conventional natural gas: $0.796 \mathrm{~kg} / \mathrm{Nm}^{3}$ ) [48], and higher heating value of $56.7 \mathrm{MJ} / \mathrm{kg}$ (or $41.1 \mathrm{MJ} / \mathrm{Nm}^{3}$ ) [49](conventional natural gas: $44.2 \mathrm{MJ} / \mathrm{Nm}^{3}$ ). So the volume of mixed gas required to produce $1 \mathrm{MWh}$ heat is 1.08 times that of conventional natural gas. The addition of hydrogen also results in a faster combustion and potential higher temperature that lead to increased $\mathrm{NO}_{\mathrm{x}}$. However, due to the high uncertainty of $\mathrm{NO}_{\mathrm{x}}$ emissions from gas boiler [50], and small variations in observed $\mathrm{NO}_{\mathrm{x}}$ emissions [48], it is assumed that $10 \%$ of hydrogen won't change the $\mathrm{NO}_{\mathrm{x}}$ emissions as of using conventional natural gas, given well-adjusted operation. The amount of $\mathrm{CO}_{2}$ emissions from SNG combustion is balanced with the $\mathrm{CO}_{2}$ that feeds into methanation to produce SNG. But when $\mathrm{CO}_{2}$ is captured from atmosphere, environmental burdens of the materials and energy consumption for capture is accounted for [51], whereas when $\mathrm{CO}_{2}$ is obtained from biogas upgrade, it is treated as a waste from biogas upgrading with no burdens associated.

As for Life Cycle Impact Assessment (LCIA) methodology, the indicators recommended by ILCD (also known as "ILCD 2011 Midpoint") [52] and implemented in Simapro 8.0.4.30 [41] are used in this study, with detailed impact method for each impact category listed in SI Table 3. Given the different levels of recommendation on impact assessment methodology (shown in Table 1 in [52]), only the ones with "recommended and satisfactory" and "recommended but in need of some improvements" (9 impact categories in total) are included in the assessment, while the impact categories classified as "recommended, but to be applied with caution" are not considered due to their high uncertainty and lack of international consensus on characterisation. The impacts considered are: climate change, ozone depletion, particulate matter, ionising radiation impact on human health, photochemical ozone formation, acidification, terrestrial eutrophication, and freshwater eutrophication. 


\subsection{Integrated assessment}

In order to integrate our techno-economic and environmental findings, we select a group of technoeconomic and environmental indicators for combined assessment. Levelised cost and value of product gas are included as the indicators for techno-economic performance, while the nine environmental impact categories mentioned above are included as indicators representing environmental performance. Furthermore, normalisation was performed in order to understand the relative performance of $11 \mathrm{KPI}$. Linear interval standardisation was chosen as method for normalisation, i.e. the value of a KPI was divided by the worst-performing option. This means that the worst and best option reach values equal to 1 and close to 0 respectively, as suggested by Eq. (7) and Eq. (8). Eq. (8) was used for the LVOES (the higher the better), while Eq. (7) was used for the rest of indicators (LCOES and environmental impacts) which can be considered as costs or impacts (the lower the better). The subindexes I and $\mathrm{j}$ refer to indicator and scenario respectively.

$$
\text { Normalised } X_{i j} \text { for LCOES and environmental impacts }=\frac{X_{i j}}{\operatorname{Max}\left(X_{i j}\right)}(7)
$$

$$
\text { Normalised } X_{i j} \text { for LVOES }=\frac{X_{i j}}{\operatorname{Min}\left(X_{i j}\right)}(8)
$$

\subsection{Sensitivity analysis}

Different components constituting a P2G plant are typically produced by different manufacturers and some of them are still in the R\&D and demonstration stages. Many pilot plants are being installed worldwide in order to test the performance in the field and gather information regarding technical performance on efficiency, degradation and durability, as well as control strategies [53]. However, seasonal data on component efficiency and system round trip efficiency are not available at the moment. In addition, there is high variability and associated uncertainty in various techno-economic parameters such as CAPEX and OPEX of the system and cost of the $\mathrm{CO}_{2}$ inflow. Since a P2G system could be operated for more than 10 years [54], the evolution of energy prices also introduces uncertainty. A sensitivity analysis was conducted to further assess the impact of key parameters based on the literature review, affecting the techno-economic and environmental performance of P2G systems. The range of values of the various parameters shown in Table 3 is based on positive and negative $30 \%$ variations relative to the baseline value except for the degradation rate of PEM electrolyser stacks since even larger variations were found in the literature [55]. The sensitivity analysis for the environmental performance is limited to life cycle GHG emissions only. 
Table 3: Different parameters included in the sensitivity analysis together with the value utilised in the baseline, the minimum and maximum case

\begin{tabular}{|c|c|c|c|c|c|}
\hline Parameter (unit) & $\begin{array}{l}\text { Techno- } \\
\text { economic }\end{array}$ & LCA & $\begin{array}{l}\text { Minimum } \\
\text { Value }\end{array}$ & Baseline & $\begin{array}{l}\text { Maximum } \\
\text { Value }\end{array}$ \\
\hline Electrolyser loading (\%) & Yes & Yes & 40 & 90 & 100 \\
\hline Stack degradation $(\mu \mathrm{V} / \mathrm{h})$ & Yes & Yes & 0.4 & 5 & 15 \\
\hline Stack durability (h) & Yes & Yes & 20000 & 50000 & 60000 \\
\hline $\begin{array}{l}\text { Total CAPEX variation } \\
\text { (\% of baseline value) }\end{array}$ & Yes & n.a & 70 & 100 & 130 \\
\hline $\begin{array}{l}\text { Total OPEX variation } \\
\text { (\% of baseline value) }^{6}\end{array}$ & Yes & n.a & 70 & 100 & 130 \\
\hline $\begin{array}{c}\text { Cost of } \mathrm{CO}_{2} \text { capture from air } \\
(\$ / \text { ton })\end{array}$ & Yes & n.a & 140 & 200 & 260 \\
\hline $\begin{array}{l}\text { Electricity price variation } \\
\text { (\% of baseline value) }\end{array}$ & Yes & n.a & 70 & 100 & 130 \\
\hline Natural gas price variation (\%) & Yes & n.a & 70 & 100 & 130 \\
\hline
\end{tabular}

\section{Results}

\subsection{System electricity consumption}

Fig. 3 shows the system electricity consumption per $\mathrm{Nm}^{3}$ of gas generated and system efficiency defined in Eq. (SI1) and Eq. (SI2) respectively as a function of the scale for P2H and P2M systems. The system's electricity consumption decreases with the electrolyser rating but it levels off quickly and remains constant beyond $1 \mathrm{MW}$ (due to the modular scale-up beyond $1 \mathrm{MW}$, see above). For larger systems, the parasitic losses associated with the required BoP increase linearly. Results follow the same pattern for both $\mathrm{P} 2 \mathrm{H}$ and $\mathrm{P} 2 \mathrm{M}$ systems but the additional energy required for methanation penalises $\mathrm{P} 2 \mathrm{M}$. The type of $\mathrm{CO}_{2}$ source does not substantially affect the system electricity consumption since for the case of $\mathrm{CO}_{2}$ capture from the air, most of the energy required (86\%) is provided in the form of low-temperature waste heat at $100{ }^{\circ} \mathrm{C}$ by the methanation reactor. However, less surplus heat is available for district applications in this case. For $\mathrm{CO}_{2}$ obtained from biogas upgrading, the biogas upgrading facility and its energy use is not within the system boundary of this study, since the supplied $\mathrm{CO}_{2}$ is considered as a burden-free waste.

\footnotetext{
${ }^{6}$ Including operational and maintenance cost of the various components within the system, namely electrolyser, methanation reactor and BoP.
} 
Fig. 3. $\mathrm{P} 2 \mathrm{G}$ system electricity consumption and efficiency of $\mathrm{P} 2 \mathrm{H}$ and $\mathrm{P} 2 \mathrm{M}$ systems (both with $\mathrm{CO}_{2}$ capture from the air and $\mathrm{CO}_{2}$ from biogas upgrading plants) using PEM technology for electrolysis depending on the scale of the installation and the type of gas produced: hydrogen (P2H) or SNG (P2M).

\subsection{Economic results}

As displayed in Fig. 4, the levelised cost decreases substantially with the size of the P2G system due to better efficiency and assumed economies of scale. However, the drop is less remarkable as the electrolyser rating increases. Increasing the system size 10-fold from $100 \mathrm{~kW}$ to $1 \mathrm{MW}$ and from $1 \mathrm{MW}$ to $10 \mathrm{MW}$ reduced the cost of generating $1 \mathrm{MWh}_{\mathrm{t}}$ (hydrogen) by $\$ 37.4$ and $\$ 10.4$, respectively. The most competitive hydrogen production cost, $\$ 85.6 / \mathrm{MWh}_{\mathrm{t}}$, would be obtained by a projected rating (still not available in operation) of $1 \mathrm{GW}$. However, this value is still substantially higher than the cost of producing hydrogen by steam reforming, $\$ 40 / \mathrm{MWh}_{\mathrm{t}}$ approximately [56]. For P2M systems, the methanation of $\mathrm{CO}_{2}$ by hydrogen reduction adds $\$ 35.0 / \mathrm{MWh}_{\mathrm{t}}(\mathrm{SNG})$ in the case of $\mathrm{CO}_{2}$ supply from a biogas plant facility (due to the extra cost of the methanation reactor and related efficiency penalty) and $\$ 85.3 / \mathrm{MWh}_{\mathrm{t}}$ (also considering the extra cost from $\mathrm{CO}_{2}$ captured from the air) for a $1 \mathrm{MW}$ system, the value of the extra cost (per unit of energy generated) also dropping with the scale of the system. The percentage contributions to levelised cost for a $\mathrm{P} 2 \mathrm{H}$ system and a $\mathrm{P} 2 \mathrm{M}$ system (with $\mathrm{CO}_{2}$ captured from the air) of $1 \mathrm{MW}$ are represented in Fig. 5. This scale is selected since it is close to the largest system available in the market at the moment [55]. The CAPEX and OPEX contribute $28 \%$ and $72 \%$ of the levelised cost for the $\mathrm{P} 2 \mathrm{H}$ system, while the CAPEX share increases to $48 \%$ for $\mathrm{P} 2 \mathrm{M}$ with $\mathrm{CO}_{2}$ from the atmosphere. 
The levelised value is less sensitive to the system scale and it decreases gently with the rating of the electrolyser. For example, the levelised value associated with a $25 \mathrm{~kW}$ plant and a $1 \mathrm{MW}$ plant is equal to $\$ 128.0 / \mathrm{MWh}_{\mathrm{t}}$ and $\$ 116.1 / \mathrm{MWh}_{\mathrm{t}}$, respectively, for $\mathrm{P} 2 \mathrm{H}$. This is related to higher yield of larger systems (thus increasing the denominator in Eq. (5) and the fact that some of the applications (reported in the numerator) are not proportional to the gas yield (e.g., frequency control and heat). Besides, the levelised value is also affected by the relatively higher importance of the residual value of the BoP for systems in the $\mathrm{kW}$ scale. However, the reader should bear in mind that the $1 \mathrm{MW}$ plant is more efficient as shown in Fig. 3. Regarding the type of gas generation, there is also more value associated with SNG than hydrogen, around $\$ 15 / \mathrm{MWh}_{\mathrm{t}}$ and $\$ 20 / \mathrm{MWh}_{\mathrm{t}}$ for plants capturing $\mathrm{CO}_{2}$ from the air and from biogas upgrading plants, respectively. Again, the value associated with some of the applications, namely frequency regulation and oxygen generation is not directly proportional to the SNG yield (used as denominator in Eq. (5). Furthermore, the $\mathrm{CO}_{2}$ atmospheric capture unit consumes all heat available from the methanation reactor reducing the heat available for district sale. Fig. 6 shows the value created by each service provided by a P2G system and how the profitability increases when they are stacked. The arrow over the red background indicates the lost value $\left(\$ 10 / \mathrm{MWh}_{\mathrm{t}}\right)$ due to the consideration of an electricity supply with imports contrary to an electricity supply with Swiss guarantee of origin.

The IRR, being the balance between the levelised cost and the levelised value, increases steadily with the system scale but the benefit of increased scale is very limited for $\mathrm{P} 2 \mathrm{M}$ systems with $\mathrm{CO}_{2}$ capture from the air due to the cost associated with $\mathrm{CO}_{2}$ capture mainly (which is assumed to not incorporate any scale benefits). Under the assumption that P2G systems could benefit from a value proposition including all the applications introduced in Section 2.2, a positive economic case is possible (i.e. internal rate of return value higher than the assumed discount rate $8 \%$ ) for $\mathrm{P} 2 \mathrm{H}$ systems and $\mathrm{P} 2 \mathrm{M}$ systems connected to biogas upgrading plants on the MW scale. Additionally, the larger the system is, the higher the profitability is, ranging from $-3.2 \%$ ( $25 \mathrm{~kW}$ ) up to $42.4 \%$ (1 GW system) for P2H (More detailed results in Figure 11). The higher CAPEX and lower efficiency of P2M systems limit the potential maximum profitability. 
Fig. 4. (a) Levelised cost; (b) levelised value; and (c) internal rate of return of P2G systems using PEM electrolysers depending on the scale of the installation and the type gas finally produced: hydrogen or SNG (P2M).

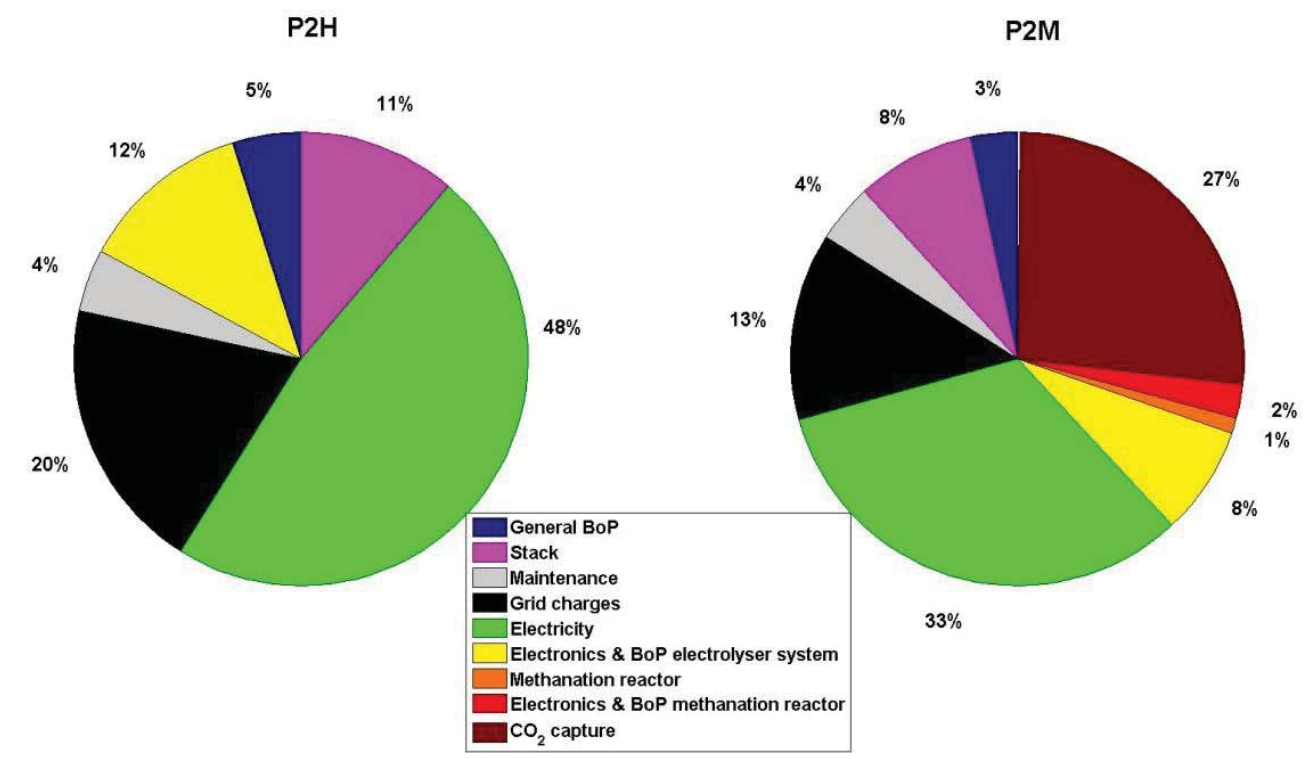

Fig. 5: Levelised cost for different cost components (both CAPEX and OPEX) as a percentage of the total for a $1 \mathrm{MW}$ $\mathrm{P} 2 \mathrm{H}$ system and a $1 \mathrm{MW}$ P2M system capturing $\mathrm{CO}_{2}$ from the air. 

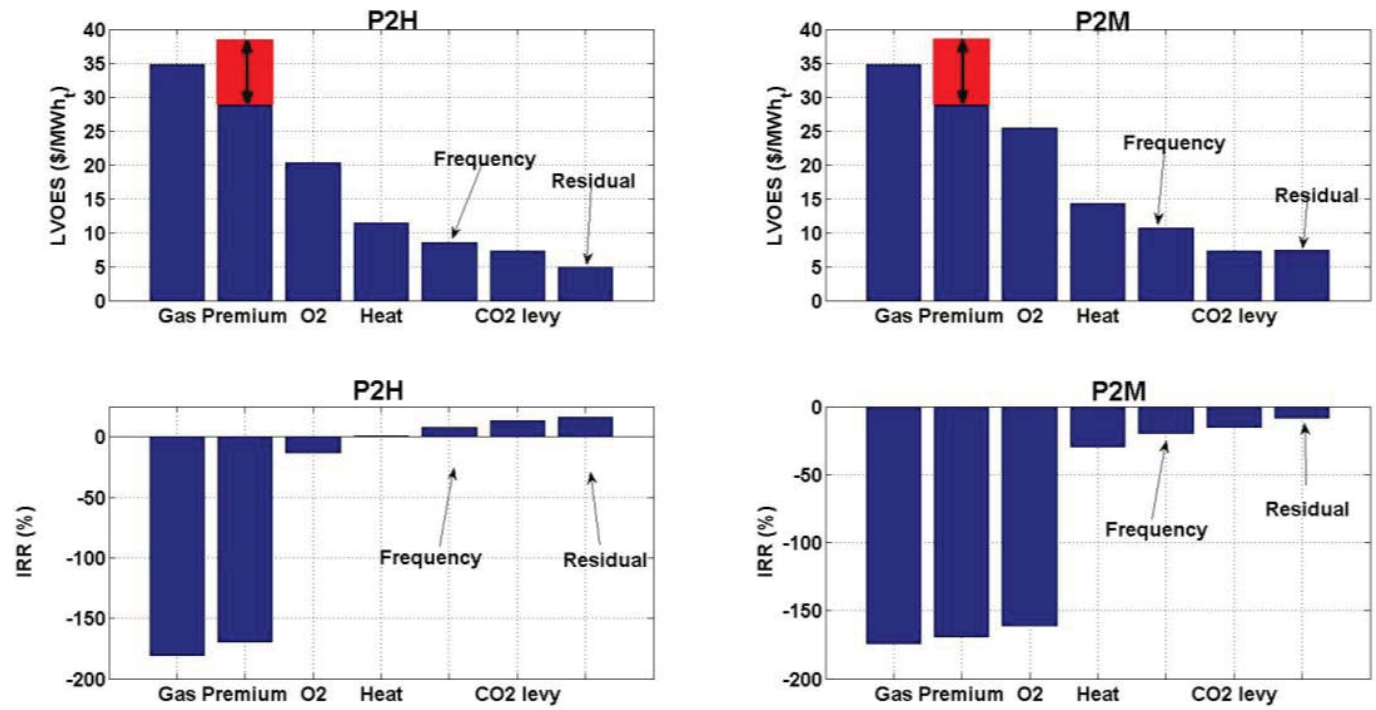

Fig. 6. Levelised value $\left(\$ / M W h_{t}\right)$ and IRR (\%) associated which services provided by a $1 \mathrm{MW} P 2 \mathrm{H}$ and a $1 \mathrm{MW}$ P2M system with $\mathrm{CO}_{2}$ capture from air. Each levelised value bar corresponds to a different service while the impact of adding an extra service to the value proposition is given for the IRR. The red bars represent the gas value lost due to electricity imports (with associated increased $\mathrm{CO}_{2}$ emissions) in comparison to a Swiss electricity supply.

\subsection{Environmental results}

The scaled potential life cycle environmental impact of hydrogen produced from $\mathrm{P} 2 \mathrm{H}$ is compared with conventional hydrogen production technologies in Fig. 7, using steam methane reforming of natural gas and coal gasification and reforming [57]. Since the percentage of hydrogen in the reference product of $\mathrm{P} 2 \mathrm{H}$ (mixture of $10 \%$ hydrogen and $90 \%$ natural gas) is small, and in order to clearly show the contribution by process in $\mathrm{P} 2 \mathrm{H}$, the figure corresponds to hydrogen generation only. The breakdown by the contribution of electricity supply, water consumption, operation and maintenance, as well as material consumption by the facility is shown.

It shows that $\mathrm{P} 2 \mathrm{H}$ with electricity supply from Swiss wholesale market has lower potential environmental impacts than conventional hydrogen production technologies in certain impact categories, including climate change, ozone depletion, particulate matter, and acidification. However, the impacts of $\mathrm{P} 2 \mathrm{H}$ are higher for ionising radiation impacts on human health and freshwater eutrophication, due to the power production from nuclear and coal, respectively. Based on the contribution analysis, it can be seen that the potential environmental impacts of $\mathrm{P} 2 \mathrm{H}$ are mostly contributed by electricity supply (more than 90\%) while the contributions from the facility, operation and maintenance, and water consumption are minor. 
Fig. 7. LCIA results for Hydrogen Generation from P2H (PEM electrolyser: $1 \mathrm{MW}$ ) vs. Hydrogen Generation from Conventional Technologies of Steam Methane Reforming, and Coal Gasification and Reforming; electricity supply to electrolysis from the Swiss wholesale market.

Due to the large contribution of electricity supply in $\mathrm{P} 2 \mathrm{H}$, the impact of different types of electricity supply is investigated and compared with conventional hydrogen generation technologies in Fig. 8, including PV, wind electricity supply in Switzerland, Swiss wholesale electricity (as applied in Fig. 7), and average European grid supply. Among these four supplies, $\mathrm{P} 2 \mathrm{H}$ with average European grid supply exhibits highest potential impacts under most of the impact categories, while supply from the electricity wholesale market causes relatively high ionising radiation impact on human health, due to its higher percentage of nuclear power supply. Swiss wind supply causes lowest impacts under most of the impact categories, due to the nickel in stainless steel required per kWh of electricity production for the wind turbines. Comparing $\mathrm{P} 2 \mathrm{H}$ with different electricity supplies with conventional hydrogen production technologies, electrolysis with EU grid supply performs worse than conventional technologies in most impact categories. When renewable electricity is supplied to electrolysis, potential impacts of $\mathrm{P} 2 \mathrm{H}$ are mostly lower than those of conventional technologies. 
Fig. 8. LCIA results for Hydrogen Generation (PEM electrolyser: $1 \mathrm{MW}$ ) with different electricity supplies to the electrolyser.

Fig. 9 shows the process contribution of $1 \mathrm{MWh}$ of heat produced by combustion of mixed fuel from P2G and conventional natural gas in a gas boiler, and they are compared with the scenario when conventional natural gas is supplied from Swiss low-pressure gas network [42]. The reference product for $\mathrm{P} 2 \mathrm{H}$ is the mixture of Swiss conventional natural gas with $10 \%$ of hydrogen by volume; and for $\mathrm{P} 2 \mathrm{M}$, the product gas is SNG, with two optional $\mathrm{CO}_{2}$ sources to produce SNG: from biogas upgrading, or from atmospheric capture. It is shown that combustion of SNG has higher potential impacts than the combustion of conventional Swiss natural gas under all impacts, even with the biogenic carbon origin of emissions (in which carbon is originally obtained from air, or biomass, which results in zero net emissions) from SNG combustion. This is because the impacts of electrolysis with supply from Swiss wholesale electricity market in P2M are much higher than the emissions of conventional natural gas production and combustion. Comparing the two P2M systems, the environmental impacts of P2M systems with $\mathrm{CO}_{2}$ captured from atmosphere are $2 \%$ to $9 \%$ higher than the system with $\mathrm{CO}_{2}$ supply from biogas upgrade, since $\mathrm{CO}_{2}$ obtained from biogas upgrade is assumed to be a waste product, and there is no impact associated with it. The contribution analysis of P2M shows that electrolysis plays a crucial role in the environmental performance of P2M, with contributions from $63 \%$ to $99 \%$ of the total environmental impacts of combustion of SNG from P2M. The environmental impact of $1 \mathrm{MWh}$ of combustion heat produced from the mixture of conventional natural gas and $10 \%$ hydrogen is in general comparable with the environmental impacts of conventional natural gas combustion: the impacts of mixed gas combustion are slightly lower than conventional natural gas combustion, under most of the impact categories, due to the lower $\mathrm{CO}_{2}$ emission and lower consumption of conventional natural gas. 


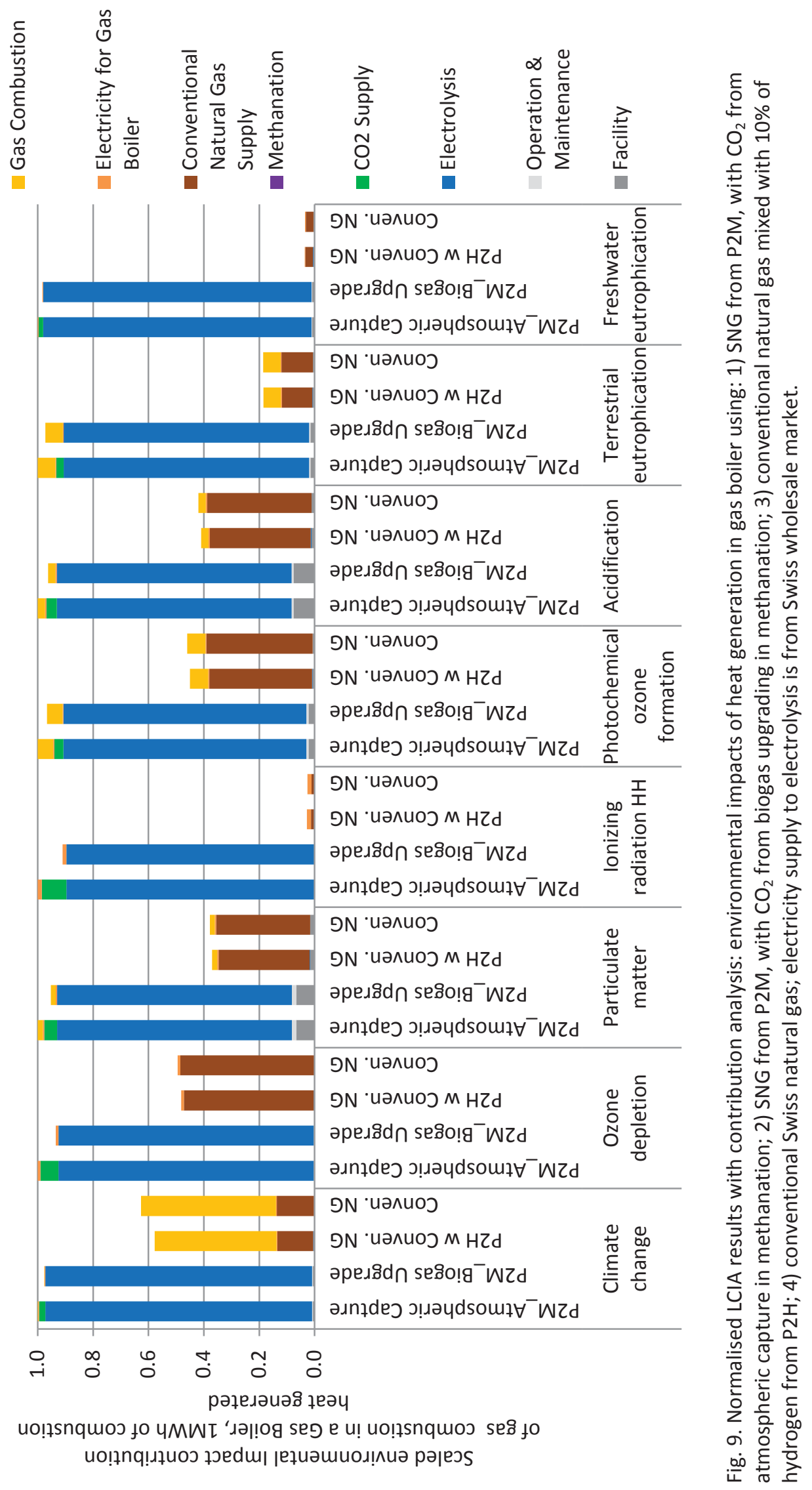




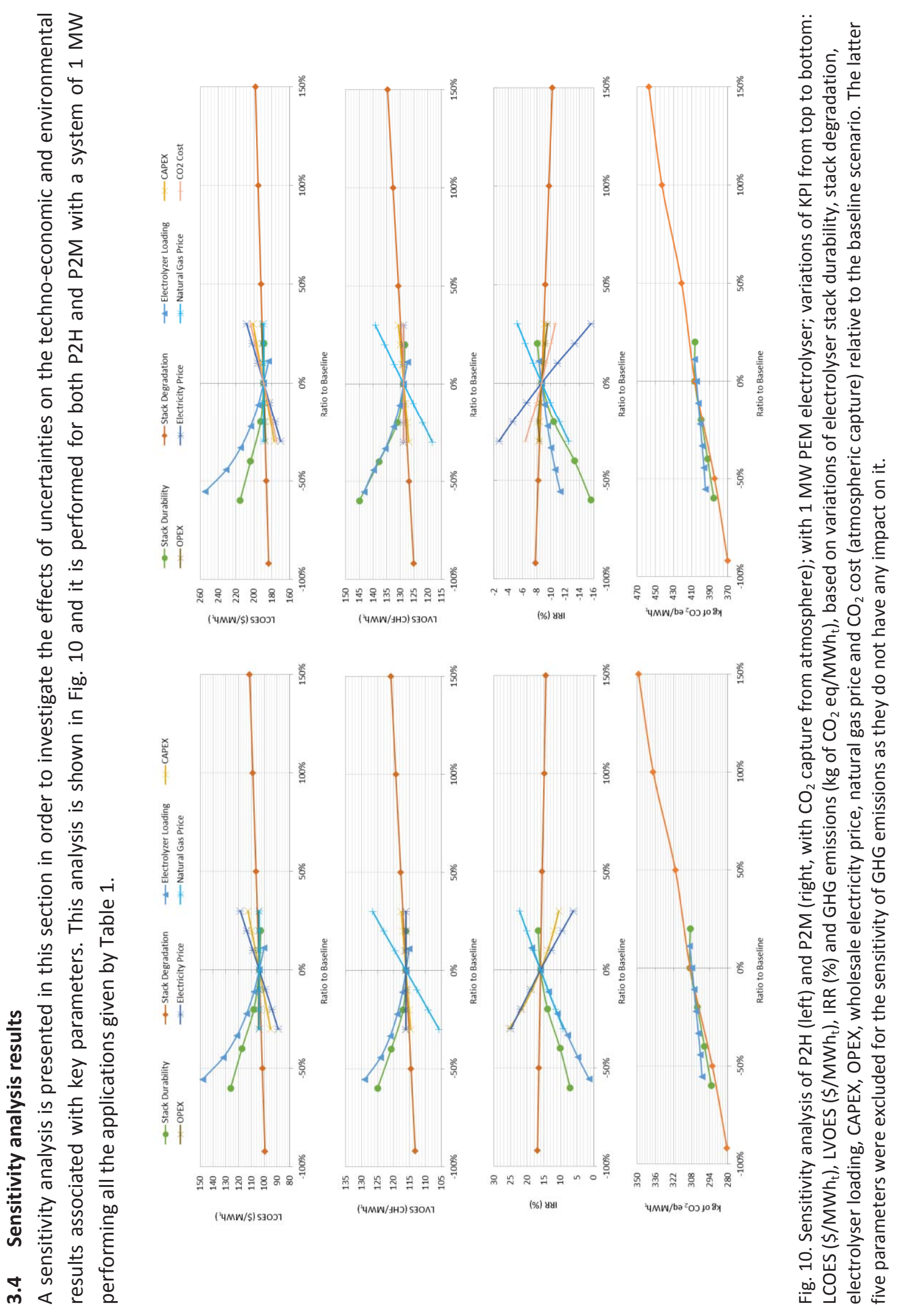


Concerning the sensitivity of system parameters on economic performance, the electricity and natural gas prices (assumed to be at the wholesale level) impact markedly on the economic benefits brought by P2G systems. The levelised cost and levelised value increase by $\$ 9.9 / \mathrm{MWh}_{\mathrm{t}}(+9.5 \%)$ and $\$ 7.0 / \mathrm{MWh}_{\mathrm{t}}$ $(+6.0 \%)$, respectively, when the price of the wholesale electricity and natural gas increase by $20 \%$, for a 1 MW P2H system. From an electrolyser technology perspective, the load factor and the stack durability are the most relevant parameters. For a P2G plant purchasing electricity in the wholesale market, operating the electrolyser close to the nominal capacity is economically beneficial. The levelised value increases at partial operation because the value created by frequency regulation does not decrease with the gas yield since it is based on the capacity (MW) instead of the gas generation. However, the main effect is the increase in levelised cost from $\$ 103.9 / \mathrm{MWh}_{\mathrm{t}}$ to $\$ 132.0 / \mathrm{MWh}_{\mathrm{t}}(27.8 \%)$ when the operation is reduced from $90 \%$ to $50 \%$, therefore reducing the profitability. Another interesting result comes from analysing the impact of the stack degradation. When the degradation rate is assumed to be $100 \%$ higher than the assumed value in the baseline scenario $(5 \mu \mathrm{V} / \mathrm{h}$ ) both the levelised cost (due to more electricity consumption) and levelised value (due to more heat generation) increase steadily but the first effect dominates. Therefore, the IRR slightly decreases with the degradation rate.

The sensitivity of durability, degradation and load factor on life cycle GHG emissions is also investigated. Results are most sensitive to degradation because the life cycle GHG emissions are dominated by electricity consumption per unit gas production, and degradation of the system increases the electricity consumption to a large extent. This is followed by electrolyser's stack durability and load factor, which show similar level of sensitivity. Durability triggers system GHG emissions through lifetime. Longer durability results in higher electricity consumption per unit gas production due to more severe system degradation at later stage of the system's lifetime. On the other hand, longer lifetime better utilises the machinery components of the system during its lifetime, which results in less environmental burdens due to material consumption per unit gas production. However, emission reduction caused by this factor is much smaller than the increase of GHG emissions caused by increased electricity consumption at the later stage of lifetime. In reality, degradation and durability are not independent factors, i.e. a higher degradation would eventually result in shorter duration in real system operation. This is however not considered in this sensitivity analysis. The maximum values of both electrolyser loading $(100 \%)$ and stack durability $(60000 \mathrm{hr}$ ) are relatively close to those selected for the baseline scenario ( $90 \%$ and $50000 \mathrm{hr}$ ). As a consequence, the differences of GHG emissions between systems with $90 \%$ and $100 \%$ of loading, 50000 and 60000 of lifetime operation hours are negligible. P2M and P2H show the same trends except that P2M has a relatively wider range of GHG emissions, mainly because the further dropped efficiency compared to $\mathrm{P} 2 \mathrm{H}$ magnifies the ranges of results.

\subsection{Combined assessment results}

The performance of all the evaluation indicators in $\mathrm{P} 2 \mathrm{H}$ and $\mathrm{P} 2 \mathrm{M}$ with different electrolyser sizes ranging from $25 \mathrm{~kW}$ to $1000 \mathrm{MW}$ is shown in Fig. 11. As an example, $\mathrm{CO}_{2}$ supply in $\mathrm{P} 2 \mathrm{M}$ is from direct atmosphere capture. Except LVOES, a clear improvement for all the other techno-economic and environmental indicators is shown when the system scale increases. The levelised cost reduces as scale increases, because of the economies of scale. The increased system size also results in overall system efficiency improvement, which reduces the electricity consumption per unit gas production, and 
therefore reduced GHG emissions. However, the improvement levels off for systems above $1 \mathrm{MW}$ because the efficiency gain of electrolyser stack does not apply any more due to the introduction of modular systems. There is still some mild improvement due to the efficiency gain of methanation unit and BoP, which results in much less reduction of electricity consumption in comparison with the reduction from the efficiency gain for system less than $1 \mathrm{MW}$. The levelised value decreases with increasing system size, since the added value of provided services and products does not increase proportionally as the amount of gas production; it is less instead, which results in the decreasing levelised value per unit of gas production. However, the absolute levelised cost decrease is greater than the levelised value decrease, which makes the overall techno-economic performance better with larger system scale.

In order to compare various techno-economic and environmental performance indicators, they are normalised according to the methodology described in section 2.3. Since hydrogen percentage in the reference product is only $10 \%$ for $\mathrm{P} 2 \mathrm{H}$, there is almost no variation of performance for different sizes. Therefore, the combined assessment is illuminated in Fig. 12 through normalised performances of P2M. The percentage of improvement in environmental performance as system scale increases is less than the improvement in economic performance, especially in comparison with the levelised cost. As the electrolyser size increases, the main effect is the relative reduction of CAPEX $(\$ / \mathrm{kW})$ due to the assumed economies of scale for the BoP. The environmental impacts are to a great extent dominated by the electricity supply, but the reduction of system energy consumption is modest. 


\begin{tabular}{|c|c|c|c|c|c|c|c|c|c|c|c|c|c|c|c|}
\hline \multirow{8}{*}{ 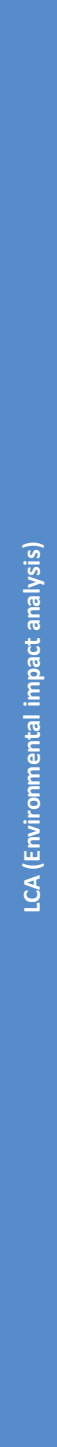 } & 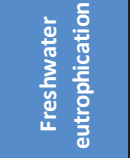 & 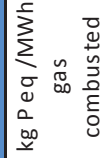 & ¿̊ & 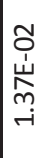 & 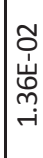 & 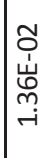 & 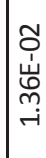 & 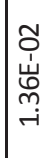 & 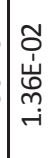 & \begin{tabular}{|l} 
\\
0 \\
$\dot{u}$ \\
8 \\
$\dot{+}$
\end{tabular} & $\left|\begin{array}{l}-1 \\
0 \\
\dot{1} \\
\ddot{\infty} \\
\infty \\
\dot{m}\end{array}\right|$ & 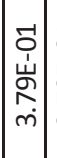 & $\mid \begin{array}{c}- \\
0 \\
\dot{1} \\
\grave{N} \\
m \\
m\end{array}$ & 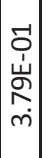 & 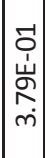 \\
\hline & 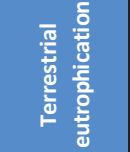 & 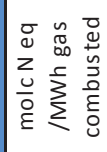 & ¿̣̊ & 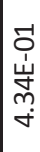 & $\begin{array}{l}\text { - } \\
\dot{1} \\
\text { m̃ } \\
m \\
\dot{\sigma}\end{array}$ & $\begin{array}{l}\text { ' } \\
\text { 山े } \\
\text { m } \\
\text { m } \\
\text { ه }\end{array}$ & 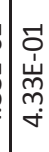 & $\begin{array}{l}-1 \\
\dot{0} \\
\dot{山} \\
m \\
\dot{\sim}\end{array}$ & $\begin{array}{l}-1 \\
0 \\
\dot{u} \\
m \\
m \\
\dot{\sigma}\end{array}$ & 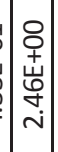 & 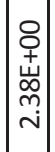 & 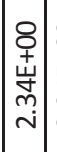 & 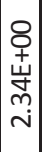 & 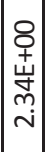 & 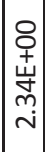 \\
\hline & 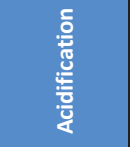 & 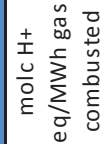 & 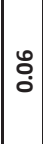 & $\begin{array}{l}\text { ó } \\
\text { 山́ } \\
\text { m } \\
\dot{\gamma}\end{array}$ & 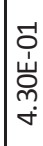 & 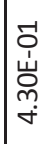 & 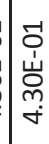 & $\begin{array}{l}\text { o- } \\
\text { ú } \\
\ddot{0} \\
\dot{\sigma}\end{array}$ & 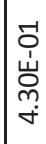 & 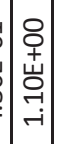 & 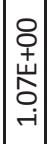 & 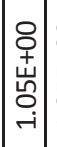 & 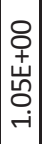 & $\mid \begin{array}{c}8 \\
+ \\
+ \\
\text { 岗 } \\
-i\end{array}$ & 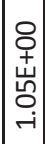 \\
\hline & 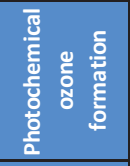 & 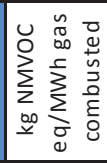 & ¿̊. & $\begin{array}{l}\text { O } \\
\dot{1} \\
\ddot{m} \\
\infty \\
\text { vi }\end{array}$ & $\begin{array}{l}\text { '- } \\
\dot{1} \\
\ddot{m} \\
\infty \\
\text { ji }\end{array}$ & $\begin{array}{l}0 \\
0 \\
\dot{1} \\
m \\
\infty \\
\sim\end{array}$ & 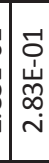 & $\begin{array}{l}\text { '- } \\
\text { ú } \\
\ddot{\infty} \\
\infty \\
\text { v }\end{array}$ & 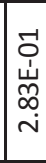 & 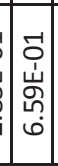 & $\mid \begin{array}{c}-1 \\
\dot{1} \\
\dot{w} \\
m \\
\text { ஸे }\end{array}$ & 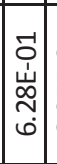 & 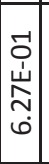 & 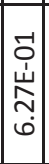 & 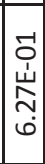 \\
\hline & 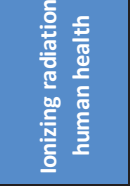 & 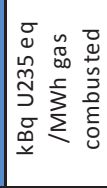 & ợ & 客 & 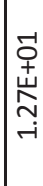 & 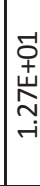 & 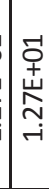 & 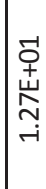 & 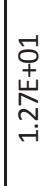 & 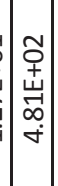 & 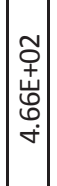 & $\begin{array}{l}\tilde{O} \\
+ \\
\dot{+} \\
\infty \\
\stackrel{\sim}{\sim} \\
\dot{\sigma}\end{array}$ & 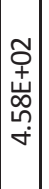 & 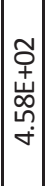 & 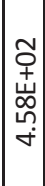 \\
\hline & 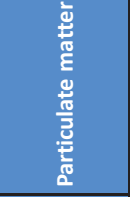 & 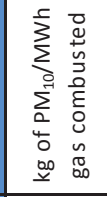 & $\stackrel{\text { Oִ }}{0}$ & $\begin{array}{l}\text { Ō } \\
\text { ú } \\
\text { ஸे } \\
\text { mे }\end{array}$ & $\begin{array}{l}\text { Õ } \\
\text { ய் } \\
\text { ஸे } \\
\text { n் }\end{array}$ & 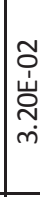 & \begin{tabular}{l}
\multirow{O}{O}{} \\
岁 \\
ñ \\
$m$
\end{tabular} & $\begin{array}{l}\widetilde{O} \\
\text { U் } \\
\text { ஸे } \\
\dot{m}\end{array}$ & 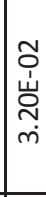 & \begin{tabular}{|c}
0 \\
0 \\
$\dot{\omega}$ \\
0 \\
$\sigma$ \\
$\sigma$
\end{tabular} & 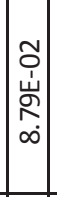 & 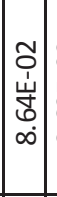 & $\begin{array}{c}0 \\
0 \\
\dot{u} \\
\tilde{n} \\
\infty \\
\infty\end{array}$ & $\left|\begin{array}{c}\tilde{O} \\
\dot{1} \\
\tilde{n} \\
\infty \\
\infty\end{array}\right|$ & $\begin{array}{c}\widetilde{O} \\
\dot{1} \\
\tilde{\tilde{n}} \\
0 \\
\infty\end{array}$ \\
\hline & 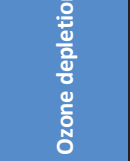 & 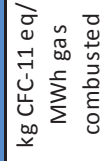 & $\begin{array}{l}0 \\
0 \\
\end{array}$ & 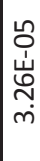 & $\begin{array}{l}\stackrel{L}{0} \\
\text { 岁 } \\
\stackrel{N}{m} \\
m\end{array}$ & 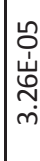 & 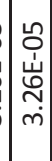 & 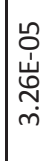 & 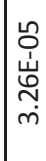 & 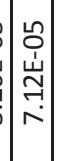 & 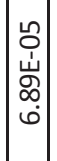 & 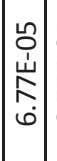 & $\mid \begin{array}{c}\qquad \\
0 \\
\dot{\omega} \\
\hat{N} \\
6 \\
\end{array}$ & $\mid \begin{array}{c}\qquad \\
0 \\
\dot{\omega} \\
\hat{N} \\
6 \\
\end{array}$ & 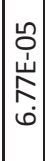 \\
\hline & 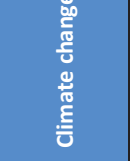 & 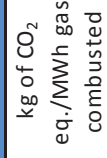 & $\stackrel{0}{0}$ & 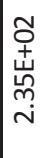 & 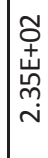 & 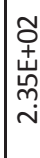 & 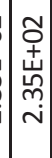 & $\begin{array}{l}\text { O } \\
+ \\
\text { 岗 } \\
m \\
\end{array}$ & 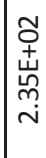 & 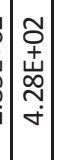 & 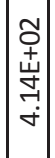 & 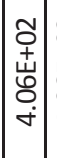 & 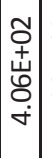 & 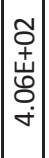 & 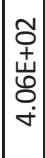 \\
\hline \multirow{2}{*}{ 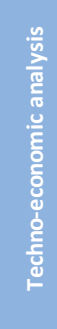 } & $\stackrel{u}{\stackrel{u}{3}}$ & $\sum_{n}^{5}$ & $\begin{array}{c}\stackrel{n}{0} \\
\mathbf{O}\end{array}$ & 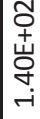 & $\begin{array}{l}\text { O } \\
+ \\
\text { 岁 } \\
\text { m. } \\
-i\end{array}$ & 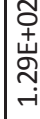 & 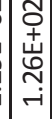 & 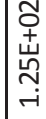 & 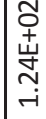 & 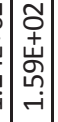 & 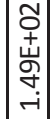 & 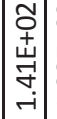 & 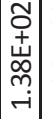 & 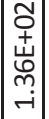 & 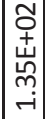 \\
\hline & 。요 & $\sum_{n=1}^{5}$ & $\underset{\mathscr{D}}{\stackrel{0}{0}}$ & 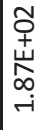 & $\begin{array}{l}\text { O } \\
\text { 岀 } \\
\text { 守 } \\
\text { - }\end{array}$ & $\begin{array}{l}\text { フ } \\
\text { † } \\
\text { 山े } \\
\text { ఫ } \\
\text { - }\end{array}$ & 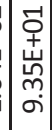 & 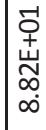 & $\begin{array}{l}-1 \\
0 \\
+ \\
\text { 㫕 } \\
\infty \\
\infty\end{array}$ & 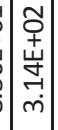 & 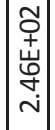 & 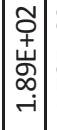 & $\left|\begin{array}{c}\tilde{O} \\
+ \\
\stackrel{+}{N} \\
-i\end{array}\right|$ & $\mid \begin{array}{c}0 \\
0 \\
+ \\
\tilde{n} \\
\text { - } \\
-i\end{array}$ & 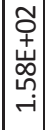 \\
\hline & 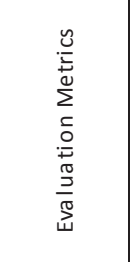 & ริ & 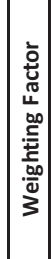 & 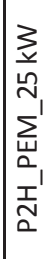 & 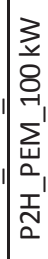 & 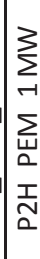 & 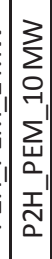 & 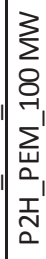 & 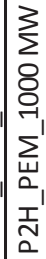 & 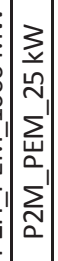 & 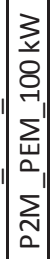 & 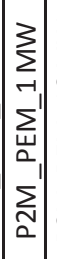 & $\left|\begin{array}{c}3 \\
\sum \\
0 \\
-1 \\
\sum_{u} \\
\vdots \\
\sum_{N} \\
\vdots \\
\vdots\end{array}\right|$ & 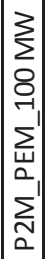 & 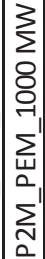 \\
\hline & & & & & & & & & & & & & & & \\
\hline
\end{tabular}

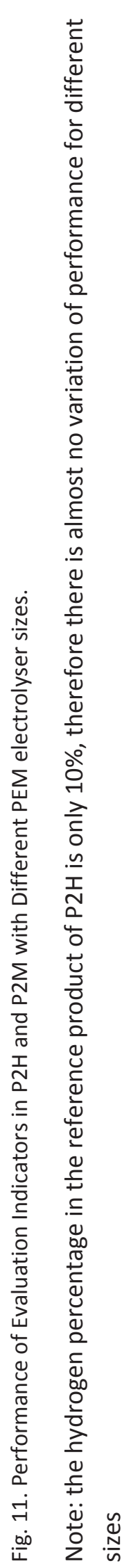




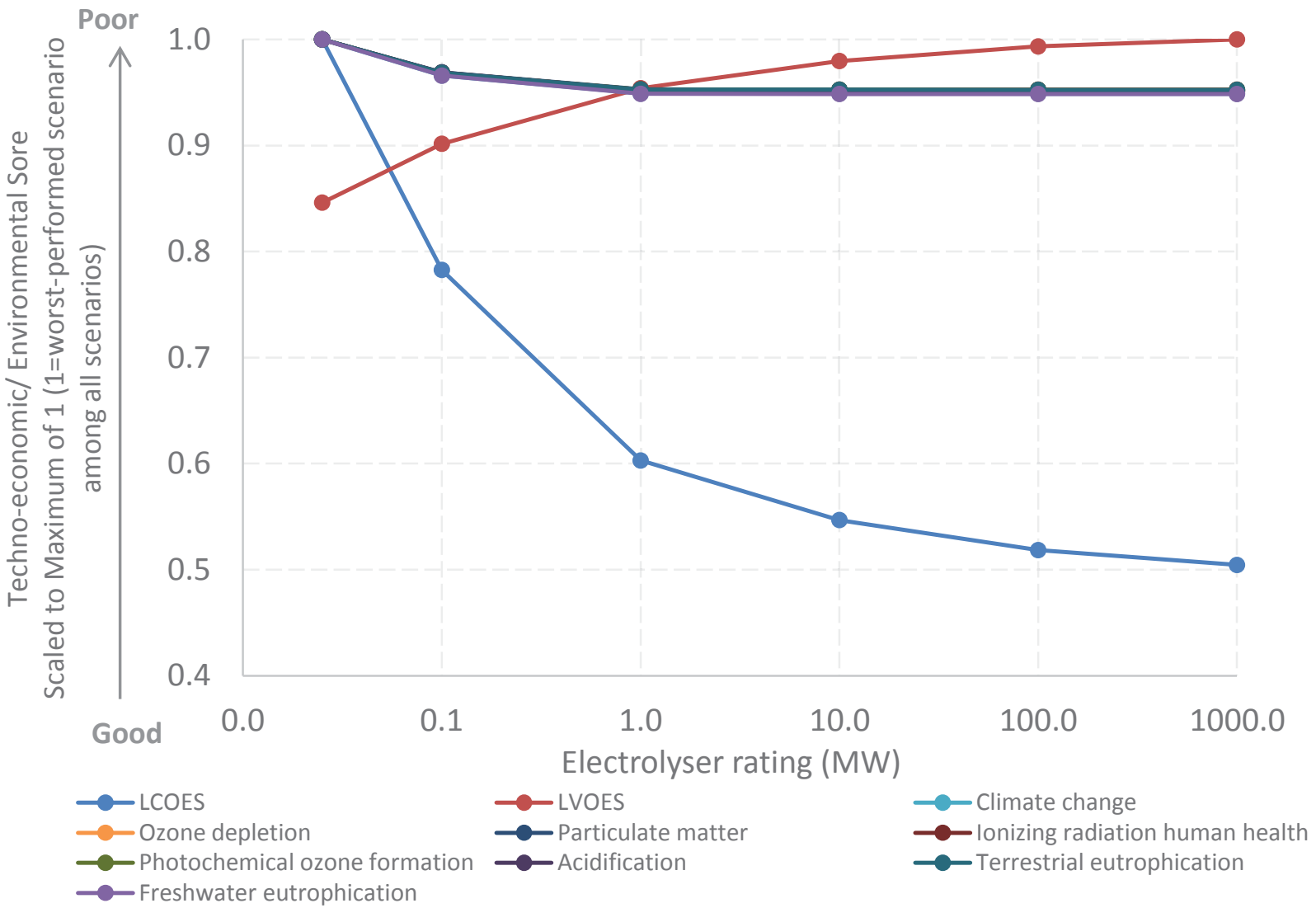

Fig. 12. Normalised techno-economic and environmental performances for P2M system, $1 \mathrm{MW}$ system, with Swiss wholesale electricity supply (including import) to PEM electrolyser, and $\mathrm{CO}_{2}$ capture from atmosphere.

\section{Discussion}

The performance of P2G systems depends on highly variable system combinations and boundary conditions which make systematic comparison across them challenging, in particular if not all assumptions are available. We compare our methods and results with some selected results published in the previous literature. A summary could be found in Table 4. Collet et al. performed technoeconomic (based on the levelised cost) and environmental assessment (based on life cycle GHG emissions and impacts at end point), but the results were not integrated for a combined assessment [23]. The life cycle emissions from Collet et al. are much lower than the emissions of P2M systems presented in this study, mainly due to the very low emissions associated with the nuclear-based French electricity supply. The levelised cost has been more widely utilised as indicator for techno-economic assessment and only two previous studies determined the economic benefits [6,37]. Our model included the variation of electricity prices and electrolyser efficiency throughout the life of the project in contrast to the rest of studies. Similar to the report prepared by ENEA [20], our model optimises the performance of a P2G system purchasing electricity from the wholesale market. They used NordPool prices from Denmark but without modelling their increase over time as well as alkaline electrolysis which explain their lower levelised cost results for $\mathrm{P} 2 \mathrm{H}$ and $\mathrm{P} 2 \mathrm{M}$. 
Table 4: Comparison of this study with other previous P2G studies

\begin{tabular}{|c|c|c|c|c|c|c|}
\hline & Assessment & Hypotheses & $\begin{array}{c}\text { LCOES } \\
\left(\$ / \mathrm{MWh}_{\mathrm{t}}\right)\end{array}$ & $\begin{array}{c}\text { LVOES } \\
\left(\$ / \mathrm{MWh}_{\mathrm{t}}\right)\end{array}$ & IRR (\%) & $\begin{array}{l}\text { Life cycle GHG } \\
\left(\mathrm{kg} \mathrm{CO}_{2} \text { eq }\right. \\
\left./ \mathrm{MWh}_{\mathrm{t}}\right)\end{array}$ \\
\hline $\begin{array}{l}\text { This } \\
\text { study }\end{array}$ & $\begin{array}{l}\text { Integrated } \\
\text { techno-economic } \\
\text { and } \\
\text { environmental }\end{array}$ & $\begin{array}{c}\text { PEM electrolyser; } \mathrm{CO}_{2} \\
\text { captured from air; optimised } \\
\text { wholesale supply }\end{array}$ & $\begin{array}{l}104 \text { (P2H), } \\
189 \text { (P2M) }\end{array}$ & $\begin{array}{l}129 \text { (P2H), } \\
141 \text { (P2M) }\end{array}$ & $\begin{array}{c}16.0(\mathrm{P} 2 \mathrm{H}) \\
8.7(\mathrm{P} 2 \mathrm{M})\end{array}$ & $\begin{array}{l}309 \text { (P2H) } \\
406 \text { (P2M) }\end{array}$ \\
\hline$[20]$ & $\begin{array}{l}\text { Techno-economic } \\
\text { and } \\
\text { environmental }\end{array}$ & $\begin{array}{l}\text { Constant electricity supply } \\
\text { and price of } \$ 32 / \mathrm{MWh}_{\mathrm{e}} 70 \% \\
\text { capacity factor; } \mathrm{CO}_{2} \text { captured } \\
\text { from air; alkaline electrolysis } \\
\text { with grid supply in France }\end{array}$ & 100 (P2M) & n.a. & n.a. & $\sim 108+(\mathrm{P} 2 \mathrm{M})^{7}$ \\
\hline$[17]$ & Techno-economic & $\begin{array}{c}\text { Generic electrolyser } 720 \\
€ / \mathrm{kW} \text {, constant electricity } \\
\text { supply and price of } \\
\$ 64 / \mathrm{MWh} ;\end{array}$ & $\begin{array}{l}148 \text { (P2H), } \\
127 \text { (P2M) }\end{array}$ & n.a. & n.a. & \\
\hline$[6]$ & Techno-economic & $\begin{array}{c}\text { Alkaline electrolyser; } \\
\text { constant electricity supply } \\
\text { and price of } \$ 60 / \mathrm{MWh} ; 100 \% \\
\text { capacity factor }\end{array}$ & $\begin{array}{l}213.8(\mathrm{P} 2 \mathrm{H}), \\
222.7 \text { (P2M) }\end{array}$ & 252.7 (P2M) & n.a. & \\
\hline [37] & Techno-economic & $\begin{array}{l}\text { PEM electrolyser; heat is sold } \\
\text { throughout the year; } \\
\text { methanation reactor } \\
\text { efficiency of } 85 \% \text {; } \mathrm{CO}_{2} \\
\text { agnostic }\end{array}$ & $\begin{array}{l}104(\mathrm{P} 2 \mathrm{H}) \\
128(\mathrm{P} 2 \mathrm{M})\end{array}$ & $\begin{array}{l}136.5(\mathrm{P} 2 \mathrm{H}) \\
146.5(\mathrm{P} 2 \mathrm{M})\end{array}$ & $\begin{array}{l}27.8(\mathrm{P} 2 \mathrm{H}) \\
16.9(\mathrm{P} 2 \mathrm{M})\end{array}$ & \\
\hline$[58]$ & Environmental & $\begin{array}{l}\text { PEM electrolyser with wind } \\
\text { power; } \mathrm{CO}_{2} \text { from flue gas of a } \\
\text { combustion plant; vehicle } \\
\text { use }\end{array}$ & n.a. & n.a. & n.a. & $49+(\mathrm{P} 2 \mathrm{H})^{8}$ \\
\hline [19] & Environmental & $\begin{array}{c}\text { Generic AEC/PEM } \\
\text { electrolyser with electricity } \\
\text { from wind, } \mathrm{PV}, \mathrm{EU}-27 \text { grid } \\
\text { mix; } \mathrm{CO}_{2} \text { from coal power } \\
\text { plant flue gas, as a waste } \\
\text { product }\end{array}$ & n.a. & n.a. & n.a. & $\begin{array}{c}18,90,828 \\
(\mathrm{P} 2 \mathrm{H}) \\
22-104,108- \\
191,994-1076 \\
(\mathrm{P} 2 \mathrm{M})^{9}\end{array}$ \\
\hline [59] & Environmental & $\begin{array}{l}\text { Alkaline electrolyser with } \\
\text { wind power; vehicle use }\end{array}$ & n.a. & n.a. & n.a. & $49(\mathrm{P} 2 \mathrm{H})^{10}$ \\
\hline
\end{tabular}

Producing hydrogen with $\mathrm{P} 2 \mathrm{H}$ systems is still much more costly ( $\$ 103.9 / \mathrm{MWh}_{\mathrm{t}}$ for a $1 \mathrm{MW} \mathrm{P} 2 \mathrm{H}$ system) than producing it with traditional methods such as natural gas steam reforming $\left(\$ 38 / \mathrm{MWh}_{\mathrm{t}}\right)$. Likewise, purchasing conventional natural gas $\left(\$ 31 / \mathrm{MWh}_{\mathrm{t}}\right)$ is less expensive by a factor of (at least) approximately 5 than producing SNG with P2M systems. However, P2G is an enabling technology which can provide several products and services simultaneously, thereby increasing the value. The extra value $\left(\$ / M W h_{t}\right)$ associated with the gas generated by a P2G system by providing low fossil-carbon gas, heat, oxygen and frequency regulation, is more than three times higher than the value of conventional natural gas for

\footnotetext{
${ }^{7}$ converted from $30+\mathrm{g} \mathrm{CO}_{2}$ eq/MJ of heat production from $\mathrm{CH}_{4}$ combustion

${ }^{8}$ converted from $10+\mathrm{g} \mathrm{CO}_{2}$ eq $/ \mathrm{MJ}$ electricity input to electrolysis, based on $25.3 \mathrm{~kg} \mathrm{H} / \mathrm{MWh}_{\mathrm{t}}$ and $0.0052 \mathrm{~kg} \mathrm{H} / \mathrm{MJ}$ of electricity input $(\mathrm{P} 2 \mathrm{H})$

${ }^{9}$ converted from 5, 25, $230 \mathrm{~g} \mathrm{CO}_{2}$ eq/MJ (P2H), and 6-29, 30-53, 276-299 $\mathrm{CO}_{2}$ eq/MJ (P2M)

${ }^{10}$ converted from $1.92 \mathrm{~kg} \mathrm{CO} 2 \mathrm{eq} / \mathrm{kg}$ of $\mathrm{H}_{2}$ based on $25.3 \mathrm{~kg} \mathrm{H} / \mathrm{MWh}_{\mathrm{t}}$
} 
systems (up to 4.5 times for a $25 \mathrm{~kW} \mathrm{P2M} \mathrm{system).} \mathrm{The} \mathrm{largest} \mathrm{economic} \mathrm{value} \mathrm{is} \mathrm{associated} \mathrm{with} \mathrm{the}$ production of gas per se (i.e. conventional natural gas, $\$ 34.7 / \mathrm{MWh}_{\mathrm{t}}$ ), followed by the premium associated with the production of nearly carbon neutral gas based on the RE content of the electricity supply $\left(\$ 28.8 / \mathrm{MWh}_{\mathrm{t}}\right)$, followed by the value of oxygen $\left(\$ 20.3 / \mathrm{MWh}_{\mathrm{t}}\right)$, heat $\left(\$ 11.5 / \mathrm{MWh}_{\mathrm{t}}\right)$, frequency control $\left(\$ 8.5 / \mathrm{MWh}_{\mathrm{t}}\right)$ and $\mathrm{CO}_{2}$ levy $\left(\$ 8 / \mathrm{MWh}_{\mathrm{t}}\right)$.

In comparison with conventional hydrogen production, $\mathrm{P} 2 \mathrm{H}$ has lower environmental impacts when the electricity supply to electrolysis is carefully selected: renewable electricity supply improves the environmental performance of $\mathrm{P} 2 \mathrm{H}$ compared to European grid supply for most impact categories. However, P2M systems using Swiss wholesale electricity for electrolysis do not show any environmental benefits regarding conventional natural gas from the Swiss grid, due to the high environmental impacts of wholesale market electricity supply (with consideration of imports from neighbouring country) to electrolysis. The environmental performance of P2M could become better than conventional natural gas supply, if the environmental impacts of electricity supply to the system were reduced by using wind or hydro power.

We finally propose some further research based on aspects not covered in this study. First, no cost is considered for the injection of product gas into natural gas network, however in reality, extra cost may be introduced by the equipment (e.g. access, meters) and usage of the natural gas network. Second, $\mathrm{P} 2 \mathrm{H}$ in the form of refuelling stations may get increase the value of hydrogen application and this could potentially be attractive for distributed P2G systems. Given the relative importance of the assumed economies of scale, changes in cost with sizes should be further addressed in future research. Some future research could also focus on the particular relationship between the price of SNG and the RE content of the electricity supplied to the electrolyser. A linear connection was established in this study as a first approximation but other type of relations could be established depending on market/customer perception and regulation. Future work should also investigate whether operating at partial load could make economic sense when wholesale electricity prices are relatively high. This decision is a trade-off among electrolyser stack efficiency, balance-of-plant consumption (both electrolyser's and general BoP which electrical consumptions are less sensitive to partial load operation) and value of electricity prices. Finally, the $\mathrm{CO}_{2}$ sources are also limited to atmospheric capture and biogas upgrading, and other potential sources such as cement plants which generate large amount of $\mathrm{CO}_{2}$ streams should be incorporated in the future.

\section{Conclusions}

At least five services (premium, gas, heat, oxygen and frequency control) and sizes larger than $1 \mathrm{MW}$ are required to create an economically profitable case (IRR larger than the assumed discount rate) for $\mathrm{P} 2 \mathrm{H}$, all six services (the previous four plus frequency control and $\mathrm{CO}_{2}$ levy) for $\mathrm{P} 2 \mathrm{M}$ with biogas upgrading, while there is no economically viable case for $\mathrm{P} 2 \mathrm{M}$ with $\mathrm{CO}_{2}$ capture from the air at the moment. At the moment, $\mathrm{P} 2 \mathrm{M}$ systems with $\mathrm{CO}_{2}$ captured from the atmosphere are not profitable (negative internal rate of return values) even when they provide multiple services regardless of the system scale. The additional CAPEX associated with $\mathrm{CO}_{2}$ captured from the air (26\% of the total levelised cost for the 1 MW P2M system) together with lower efficiency lead to relatively high levelised cost. 
The still comparatively high cost of PEM stacks $(\$ 1000 / \mathrm{kW}$ in comparison with alkaline technology, around $\$ 500 / \mathrm{kW}$ ) should not be the main barrier for the deployment of PEM electrolysers for P2G systems, since the contribution of the PEM electrolyser stack is $11 \%$ for $\mathrm{P} 2 \mathrm{H}$ (these figures are even lower for P2M systems). In contrast to small scale batteries which are close to economic viability by increasing PV power self-consumption in the residential sector in some countries such as Germany and Australia [60], P2G could bring more economic benefits at the grid-scale level (i.e., MW scale). However, factors such as potential higher value in the transport applications (e.g. hydrogen from $\mathrm{P} 2 \mathrm{H}$ being directly sold as fuel to vehicles) as well as existing incentives, regulations and market structure could also influence the economic attractiveness of more distributed P2G applications, which require further analysis.

Techno-economic and environmental Improvements are resulted with system scale, but it is less sensitive in environmental impacts since they are dominated by the amount of electricity consumption, which is not very sensitive to system scale. The environmental performance of both $\mathrm{P} 2 \mathrm{H}$ and $\mathrm{P} 2 \mathrm{M}$ is dominated by the amount and type of electricity supply to electrolysis, contributing more than $90 \%$ to the LCIA results for all indicators included in this analysis (the contributions from facility infrastructure, water supply, operation and maintenance are below 10\%). The environmental impacts of $\mathrm{P} 2 \mathrm{M}$ with $\mathrm{CO}_{2}$ obtained from biogas upgrading are $2 \%$ to $9 \%$ lower than the system with $\mathrm{CO}_{2}$ from atmospheric capture, since $\mathrm{CO}_{2}$ from biogas upgrading is considered as a waste, and thus its environmental burdens are not accounted for.

\section{Acknowledgement}

This work is funded by the Commission for Technology and Innovation in Switzerland within the project of SCCER-HaE (Swiss Competence Centre for Energy Research in Heat and Electricity Storage; with contract no.:1155000153) and by the Energy System Integration (ESI) platform of PSI. 


\section{Supplementary Information}

\subsection{Technical performance assessment methodology and input data}

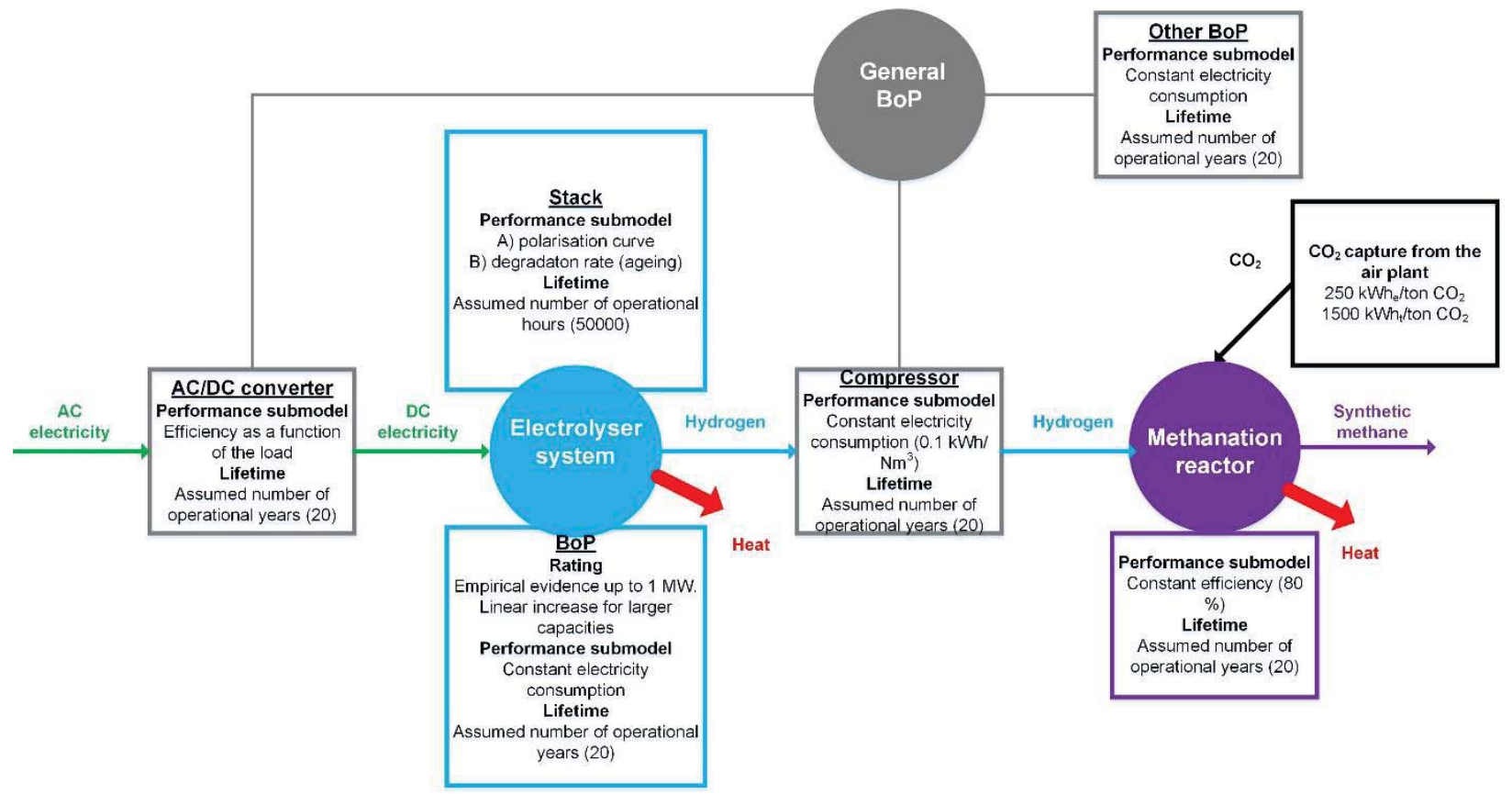

SI Fig. 1. Key characteristics of the technical model for main components of a P2G system.

The technical analysis is based on a primary energy balance including of a P2G plant (see Fig. 1) as a physical system and the relationships with the surroundings (namely electricity consumption, gas supply to the network and $\mathrm{CO}_{2}$ supply). This energy balance was then complemented with a material balance. For each component represented in Fig. 1, a dedicated submodel was developed to model the energy conversion and related losses occurring in it. A comprehensive explanation of the different submodels can be found in a previous study [39] therefore only essential elements explaining the rationale are introduced below and also summarised in SI Fig. 1. Not all the heat generated by a P2G plant, namely electrolyser and methanation reactor at $80^{\circ} \mathrm{C}$ and $250-300^{\circ} \mathrm{C}$ respectively, can be harnessed for district heating applications. The model includes a heat exchanger with an efficiency of $90 \%$ to consider losses occurring in a real system.

The total electricity consumption of a P2G plant, $E_{e}\left(M W h_{e}\right)$, is the addition of the electricity consumption of all its components, namely electrolyser system (including both stack and its specific balance-of-plant, BoP), AC/DC converter, compressor, methanation reactor (for SNG production only) and general BoP of the P2G system. The specific system electricity consumption of a P2G plant, $S C_{P 2 G}$ $(\mathrm{kWh} / \mathrm{kg})$, quantifies the amount of electricity necessary to produce $1 \mathrm{~kg}$ of gas (hydrogen or SNG) and is calculated using Eq. $(S \mid 1)$ where $m_{g}(\mathrm{~kg})$ refers to the gas production during the hour $h$, this production being aggregated throughout the total number of hours the electrolyser lasts for, Life ( $h$ ). Another 
related KPI is the system efficiency, which is defined as the ratio between the thermal energy content of the gas production $\mathrm{E}_{\mathrm{g}}\left(\mathrm{MWh}_{\mathrm{t}}\right)$ and the total electricity consumption as indicated by Eq. (SI2).

$$
\begin{gathered}
S C_{P 2 G}=\frac{\sum_{h=1}^{\text {Life }} E_{e_{i}}}{\sum_{h=1}^{L i f e} m_{g_{i}}} \\
\eta=\frac{\sum_{h=1}^{\text {Life } E_{g_{i}}}}{\sum_{h=1}^{\text {Life } E_{e_{i}}}}
\end{gathered}
$$

The technical performance of the electrolyser system was modelled following a bottom-up approach considering both the cell stack and BoP. The PEM electrolyser model is based on data from the UK manufacturer ITM-power [22]. The cell area increases with the rating of the electrolyser, for example $0.01 \mathrm{~m}^{2}$ and $0.03 \mathrm{~m}^{2}$ for a $25 \mathrm{~kW}$ and $1 \mathrm{MW}$ electrolyser system respectively. The performance of a PEM electrolyser cell was characterised by means of its polarisation curve, represented in SI Fig. 2, i.e. the amount of voltage required to produce a given amount of hydrogen (which is linear to the current density represented in abscissas). The electrolysis voltage is always higher than the thermodynamic voltage (referred in the graph as Nernst voltage) since several losses occur during the hydrogen generation process, namely chemical activation in both the cathode and anode; and ohmic losses mainly due to the transport of hydrogen protons in the PEM membrane [61]. Additionally, the model accounts for the losses due to reactants and products gradient concentrations at the reaction sites [62]. It was assumed that the performance of an electrolyser stack is the addition of the performance of several electrolyser cells while the area of one cell was taken from the literature [63]. Finally, steady state performance close to nominal condition (load factor equal to $90 \%$ ) was assumed, in agreement with previous P2G techno-economic studies including operation in the wholesale electricity market $[6,17]$. Specifically, an operational current density equal to $1.8 \mathrm{~A} / \mathrm{cm}^{2}$ was selected as shown in SI Fig. 2. These values mean an operation voltage equal to $1.94 \mathrm{~V}$ for fresh cells which are in agreement with those published in the recent literature $[64,65]$. Different values for the key input and output data of the PEM cell model are summarised in Table 2. 
SI Fig. 2. Polarisation curve of a single PEM cell including the thermodynamic voltage and other losses occurring at the anode, cathode and membrane as modelled in this study.

The rating of the electrolyser's BoP (including deioniser water system, thermal management and control) was determined based on empirical data from current electrolyser systems available in the market [15, 66]. For ratings larger than the maximum scale available in the market at the moment (6 MW), a linear increase in the rating of the BoP was assumed since larger electrolyser systems comprise several stacks in parallel due to cell area constraints [15]. Besides, the consumption of the electrolyser's BoP was assumed to be constant in agreement with other previous studies [25,67].

In addition to the electrolyser system (including both stack and BoP), the rest of components modelled were the $A C / D C$ converter, the compressor, the general BoP; and the methanation reactor and $\mathrm{CO}_{2}$ capture plant in the case of P2M. A dynamic efficiency curve as a function of the load factor as shown in SI Fig. 3 was used for the AD/DC converter based on the state-of-art of this electronic equipment [68]. A constant electricity consumption of the hydrogen compressor equal to $0.1 \mathrm{kWh} / \mathrm{Nm}^{3}$ was assumed considering the maximum pressure level of the natural gas network in Switzerland (70 bar) [6] while the methanation reactor was assumed to perform with a constant efficiency equal to $80 \%$ based on standard values published in the literature. This efficiency typically ranges between 70-85\% [36, 69]. For $\mathrm{CO}_{2}$ capture from the atmosphere, the electricity and heat requirements given in SI Fig. 1 were assumed [32], with the latter being totally supplied by the methanation reactor. 


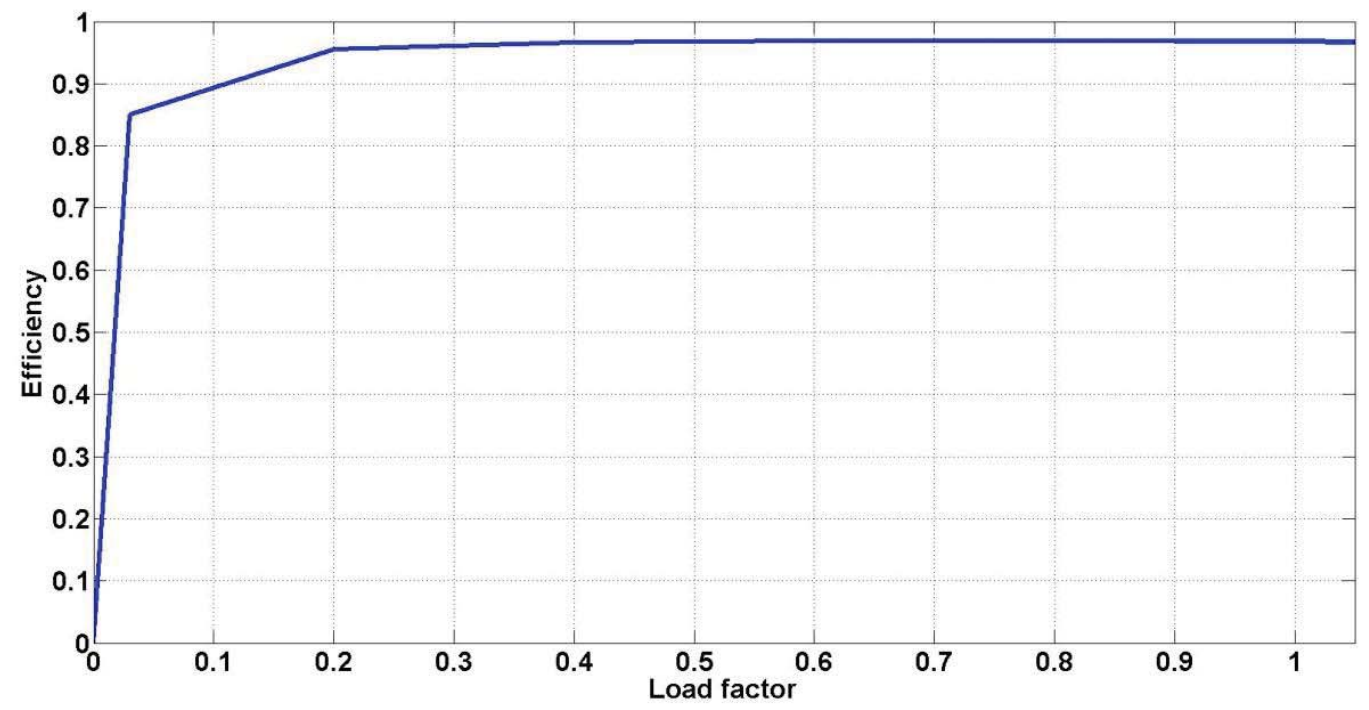

SI Fig. 3. AC/DC converter efficiency as a function of the load factor [68].

Finally, the durability of the various components was also included in the P2G model. This was assumed to be equal to 20 years for the various BoP components based on standard values but the durability of the stack was assumed to come to an end when the electrolyser reached a maximum number of operational hours based on the current state-of-art of PEM technology (see Table 2 for selected values in the baseline scenario). At the same time, ageing in the form of thermal and electrochemical degradation occurs throughout operation of the electrolyser which gradually becomes less efficient (voltage increase) [70]. Therefore, the model dynamically accounted for this phenomenon by considering the stack's degradation rate which was assumed to be equal to $5 \mu \mathrm{V} / \mathrm{h}$.

\subsection{Wholesale electricity prices}
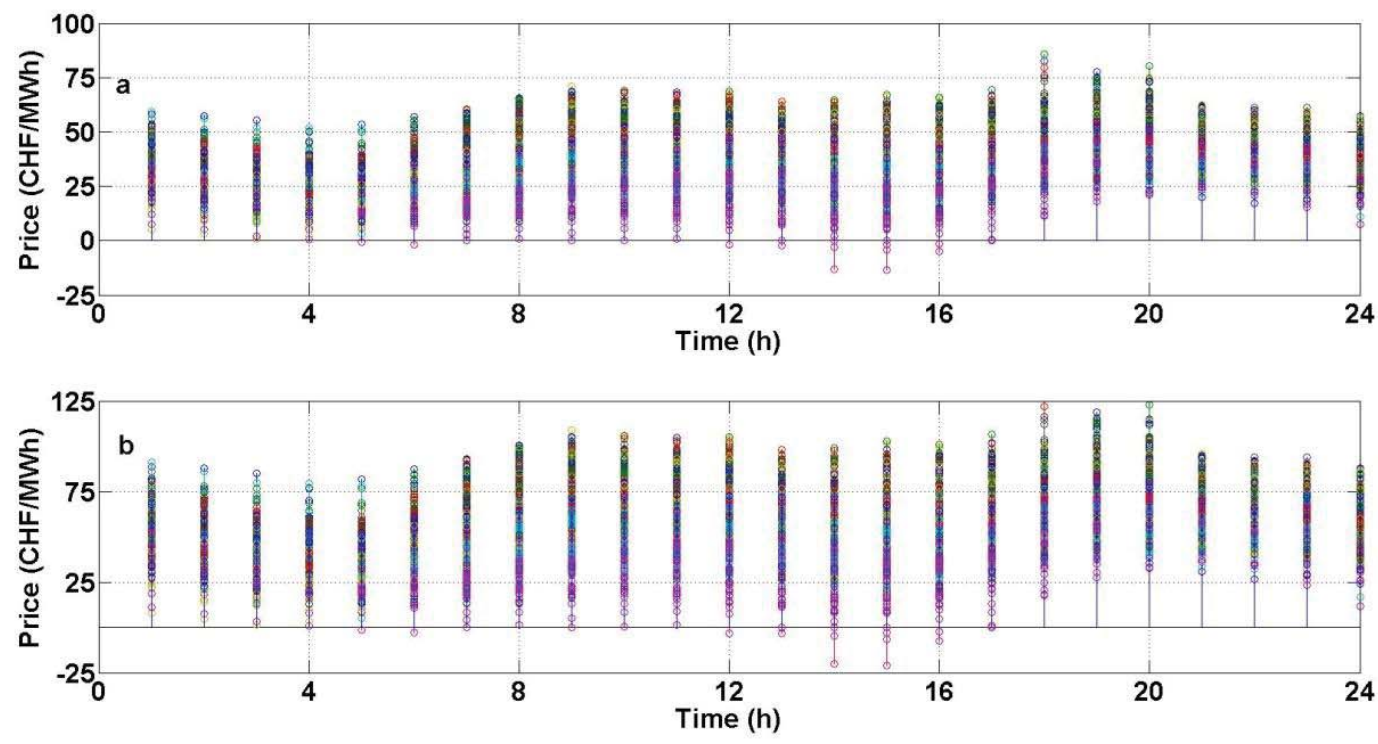
SI Fig. 4. Swiss wholesale electricity throughout every day of the year in (a) 2014 (real data); and (b) 2030 (using the results from the Swissmod model [24].

\subsection{Technology share of Swiss wholesale electricity considering import}

SI Table 1: Average mix of Swiss wholesale electricity during system lifetime (2015-2024), calculated based on technical model result (annual electricity consumption of electrolyser stack) and Swissmod annual supply mix [27]

\begin{tabular}{|ll|}
\hline Electricity Supply & $\begin{array}{l}\text { \% of Supply in Swiss } \\
\text { Wholesale Market }\end{array}$ \\
\hline Electricity, Geothermal & $0.12 \%$ \\
\hline Electricity, Wind & $8.6 \%$ \\
\hline Electricity, Photovoltaics & $3.7 \%$ \\
\hline Electricity, Cogeneration & $1.1 \%$ \\
\hline Electricity, Nuclear & $26.0 \%$ \\
\hline Electricity, Lignite & $7.8 \%$ \\
\hline Electricity, Hard coal & $9.4 \%$ \\
\hline Electricity, Hydro & $31.9 \%$ \\
\hline Electricity, Waste & $0.5 \%$ \\
\hline Electricity, Wood & $4.0 \%$ \\
\hline Electricity, Natural gas & $6.2 \%$ \\
\hline Electricity, Oil & $0.6 \%$ \\
\hline
\end{tabular}

\subsection{Environmental impact contribution of $\mathbf{P 2 H}$}

SI Table 2: Environmental impact contribution of $\mathrm{P} 2 \mathrm{H}$

\begin{tabular}{|lrrrr|} 
Climate change & Facility & $\begin{array}{c}\text { Operation \& } \\
\text { Maintenance }\end{array}$ & Water & $\begin{array}{l}\text { Electricity } \\
\text { supply }\end{array}$ \\
\hline Ozone depletion & $2 \%$ & $3 \%$ & $0 \%$ & $95 \%$ \\
\hline Particulate matter & $0 \%$ & $0 \%$ & $0 \%$ & $100 \%$ \\
\hline lonising radiation HH & $12 \%$ & $5 \%$ & $0 \%$ & $83 \%$ \\
\hline Photochemical ozone formation & $0 \%$ & $0 \%$ & $0 \%$ & $100 \%$ \\
\hline Acidification & $6 \%$ & $4 \%$ & $0 \%$ & $90 \%$ \\
\hline Terrestrial eutrophication & $27 \%$ & $3 \%$ & $1 \%$ & $69 \%$ \\
\hline Freshwater eutrophication & $3 \%$ & $3 \%$ & $1 \%$ & $93 \%$ \\
\hline
\end{tabular}

\subsection{Environmental impact categories and methodology}

SI Table 3: Impact Categories and Their Recommended Methodology by ILCD [71] 


\begin{tabular}{|c|c|c|}
\hline Impact Category & $\begin{array}{l}\text { Unit of } \\
\text { Characterisation } \\
\text { Factor }\end{array}$ & $\begin{array}{l}\text { Recommended Method } \\
\text { by ILCD } 2011 \text { [71] }\end{array}$ \\
\hline Climate change & $\mathrm{kg} \mathrm{CO}_{2} \mathrm{eq}$ & $\begin{array}{l}\text { Baseline model, } 100 \text { years, IPCC } 2007 \\
\text { [72] }\end{array}$ \\
\hline Ozone depletion & Kg CFC-11 eq & $\begin{array}{l}\text { Steady-state ODPs } 1999 \text { as in WMO } \\
\text { assessment [73] }\end{array}$ \\
\hline Human toxicity, caner effects & CTUh & $\begin{array}{l}\text { USEtox model (Rosenbaum et al, } 2008 \\
\text { [74]) }\end{array}$ \\
\hline Human toxicity, non-cancer effect & CTUh & $\begin{array}{l}\text { USEtox model (Rosenbaum et al, } 2008 \\
\text { [74]) }\end{array}$ \\
\hline Particulate matter & $\mathrm{kg} \mathrm{PM}_{2.5}$ eq & $\begin{array}{l}\text { RiskPoll model (Rabl and Spadaro, } 2004 \\
\text { [75]) and Greco et al, } 2007 \text { [76] }\end{array}$ \\
\hline Ionising radiation on human Health & $\mathrm{kBq} \mathrm{U}_{235}$ eq & $\begin{array}{l}\text { Human health effect model as developed } \\
\text { by Dreicer et al, } 1995[77,78]\end{array}$ \\
\hline Ionising radiation on ecosystem & CTUe & USEtox model [79] (interim) \\
\hline Photochemical ozone formation & Kg NMVOC eq & $\begin{array}{l}\text { LOTOS-EUROS, Van Zelm et al, } 2008 \text { [80], } \\
\text { as applied in ReCiPe }\end{array}$ \\
\hline Acidification & molc $\mathrm{H}^{+}$eq & $\begin{array}{l}\text { Accumulated Exceedance (Seppälä et al. } \\
2006 \text { [81], Posch et al, } 2008 \text { [82]) }\end{array}$ \\
\hline Terrestrial eutrophication & molc $\mathrm{N}$ eq & $\begin{array}{l}\text { Accumulated Exceedance (Seppälä et al. } \\
2006 \text { [81], Posch et al, } 2008 \text { [82]) }\end{array}$ \\
\hline Freshwater eutrophication & kg P eq & $\begin{array}{l}\text { EUTREND model (Struijs et al, } 2009 \text { [83]) } \\
\text { as implemented in ReCiPe }\end{array}$ \\
\hline Marine eutrophication & kg N eq & $\begin{array}{l}\text { EUTREND model (Struijs et al, } 2009 \text { [83]) } \\
\text { as implemented in ReCiPe }\end{array}$ \\
\hline Freshwater ecotoxicity & CTUe & $\begin{array}{l}\text { USEtox model (Rosenbaum et al, } 2008 \\
\text { [74]) }\end{array}$ \\
\hline Land use & kg C deficit & $\begin{array}{l}\text { Model based on Soil Organic Matter } \\
\text { (SOM) (Milà i Canals et al, } 2007 \text { [84]) }\end{array}$ \\
\hline Water resource depletion & $\mathrm{m}^{3}$ water eq & $\begin{array}{l}\text { Model for water consumption as in Swiss } \\
\text { Ecoscarcity (Frischknecht et al, } 2008 \text { [85]) }\end{array}$ \\
\hline
\end{tabular}

\section{References}

[1] Guandalini G, Campanari S, Romano MC. Power-to-gas plants and gas turbines for improved wind energy dispatchability: Energy and economic assessment. Applied Energy. 2015;147:117-30. 
[2] IEA. Technology Road Map Energy Storage. 9 rue de la Fédération 75739 Paris Cedex 15, France: International Energy Agency; 2014.

[3] Parra Mendoza D. Optimum community energy storage for end user applications: University of Nottingham; 2014.

[4] Ibrahim H, Ilinca A, Perron J. Energy storage systems-characteristics and comparisons. Renewable and sustainable energy reviews. 2008;12:1221-50.

[5] Sytze de Boer H, Grond L, Moll H, Benders R. The application of power-to-gas, pumped hydro storage and compressed air energy storage in an electricity system at different wind power penetration levels. Energy. 2014;72:360-70.

[6] Hofstetter D, Battke B, Cox B, Hughes J. Power-to-Gas in Switzerland - Demand, Regulation, Economics, Technical Potential. 2014.

[7] Devlin J, Li K, Higgins P, Foley A. A multi vector energy analysis for interconnected power and gas systems. Applied Energy. 2016.

[8] Garmsiri S, Rosen MA, Smith GR. Integration of Wind Energy, Hydrogen and Natural Gas Pipeline Systems to Meet Community and Transportation Energy Needs: A Parametric Study. Sustainability. 2014;5:2506-26.

[9] Lehner M, Tichler R, Steinmüller H, Koppe M. Power-to-gas technology and business model. Austria: Springer; 2014.

[10] Engerati. Germany's Power to Gas Pilots - A Real World Solution. 2013.

[11] Altfeld K, Pinchbeck D. Admissible Hydrogen Concentrations in Natural Gas Systems. DIV Deutscher Industrieverlag GmbH; 2013.

[12] Reiter G, Lindorfer J. Evaluating CO2 sources for power-to-gas applications - A case study for Austria. Journal of CO2 Utilization. 2015;10:40-9.

[13] Wilson D. Powe-to-gas Technology and Business Model Progress. Hydrogenics Corporation; 2013.

[14] Felgenhauer M, Hamacher T. State-of-the-art of commercial electrolyzers and on-site hydrogen generation for logistic vehicles in South Carolina. International Journal of Hydrogen Energy. 2015;40:2084-90.

[15] Bertuccioli L, Chan A, Hart D, Lehner F, Madden B, Standen E. Development of water electrolysis in the European Union Final Report. E4tech Sàrl with Element Energy Ltd for the Fuel Cells and Hydrogen Joint Undertaking2014.

[16] Zucker A, Hinchliffe T, Spisto A. Assessing storage value in electricity markets. JRC Scientific and Policy Report. 2013.

[17] Schiebahn S, Grube T, Robinius M, Tietze V, Kumar B, Stolten D. Power to gas: Technological overview, systems analysis and economic assessment for a case study in Germany. International Journal of Hydrogen Energy. 2015;40:4285-94.

[18] Bhandari R, Trudewind CA, Zapp P. Life cycle assessment of hydrogen production via electrolysis - a review. Journal of Cleaner Production. 2014;85:151-63.

[19] Reiter G, Lindorfer J. Global warming potential of hydrogen and methane production from renewable electricity via power-to-gas technology. Int J Life Cycle Assess. 2015;20:477-89.

[20] Consulting E. The potential of power-to-gas. Technology review and economic potential assessment. 2016.

[21] Barbour E, Wilson IG, Bryden IG, McGregor PG, Mulheran PA, Hall PJ. Towards an objective method to compare energy storage technologies: development and validation of a model to determine the upper boundary of revenue available from electrical price arbitrage. Energy \& Environmental Science. 2012;5:5425-36.

[22] Connolly D, Lund H, Finn P, Mathiesen BV, Leahy M. Practical operation strategies for pumped hydroelectric energy storage (PHES) utilising electricity price arbitrage. Energy Policy. 2011;39:4189-96. 
[23] Collet P, Flottes E, Favre A, Raynal L, Pierre H, Capela S, et al. Techno-economic and Life Cycle Assessment of methane production via biogas upgrading and power to gas technology. Applied Energy. 2016.

[24] Görgün H. Dynamic modelling of a proton exchange membrane (PEM) electrolyzer. International journal of hydrogen energy. 2006;31:29-38.

[25] Parra D, Gillott M, Walker GS. The role of hydrogen in achieving the decarbonization targets for the UK domestic sector. International Journal of Hydrogen Energy. 2014;39:4158-69.

[26] European Power Exchange ES. EPEX SPOT. 2014.

[27] Schlecht I, Weigt H. Swissmod-A Model of the Swiss Electricity Market. Available at SSRN 2446807. 2014.

[28] Prognos A. Die Energieperspektiven für die Schweiz bis 2050. Swiss Federal Office of Energy SFOE; 2012.

[29] Le Truong N, Gustavsson L. Minimum-cost district heat production systems of different sizes under different environmental and social cost scenarios. Applied Energy. 2014;136:881-93.

[30] Short W, Packey DJ, Holt T. A manual for the economic evaluation of energy efficiency and renewable energy technologies: University Press of the Pacific; 2005.

[31] Wurzbacher M. Personal conversation by e-mail. 2016.

[32] Climeworks. Climeworks CO2 Capture Plant. 2016.

[33] Lehner M, Tichcler R, Steinmüller H, Koppe M. Power-to-gas technology and business model. Austria: Springer; 2014.

[34] Francesco Massari MW, Roland Kaeppner Ismael Aso, Roberto Rasoini, Florencio Gamallo. Alkaline 2.0-Novel and advanced electrolyzers for a sutainable integration of renewable energy and implementation of a decarbonized private and public transport in Europe. 20th World Hydrogen Energy Conference 20142014.

[35] Grond L, Schulze P, Holstein J. Systems Analyses Power to Gas: Technology Review. Groningen: DNV KEMA Energy \& Sustainability; 2013.

[36] Sterner M. Bioenergy and renewable power methane in integrated $100 \%$ renewable energy systems: Limiting global warming by transforming energy systems: kassel university press $\mathrm{GmbH} ; 2009$.

[37] Gutiérrez-Martín F, Rodríguez-Antón L. Power-to-SNG technology for energy storage at large scales. International Journal of Hydrogen Energy. 2016;41:19290-303.

[38] Lieberman MB. Market growth, economies of scale, and plant size in the chemical processing industries. The Journal of Industrial Economics. 1987:175-91.

[39] Parra D, Patel MK. Techno-economic implications of the electrolyser technology and size for powerto-gas systems. International Journal of Hydrogen Energy. 2016.

[40] ISO. 14040 Environmental management - Life cycle assessment - Principles and framework Second edition ed. Switzerland2006.

[41] PRé. SimaPro 8.0.4.30 Multi user. PRé Consultants bv, Stationsplein 121, 3818 LE Amersfoort, The Netherlands2014.

[42] ecoinvent. The ecoinvent LCA database, v3.1, "cut-off by classification". The ecoinvent center; 2014.

[43] Tillman A-M. Significance of decision-making for LCA methodology. Environmental Impact Assessment Review. 2000;20:113-23.

[44] Zhang X, Bauer C, Mutel CL, Volkart K. Life Cycle Assessment of Power-to-Gas: Approaches, system variations and their environmental implications. Applied Energy. 2017;190:326-38.

[45] Treyer K, Bauer C. Life cycle inventories of electricity generation and power supply in version 3 of the ecoinvent database-part I: electricity generation. Int J Life Cycle Assess. 2016;21:1236-54.

[46] Treyer K, Bauer C. Life cycle inventories of electricity generation and power supply in version 3 of the ecoinvent database-part II: electricity markets. Int J Life Cycle Assess. 2016;21:1255-68. 
[47] Melaina MW, Antonia O, Penev M. Blending Hydrogen into Natural Gas Pipeline Networks: A Review of Key Issues. National Renewable Energy Laboratory (NREL); 2013.

[48] Cozzi F, Coghe A. Behavior of hydrogen-enriched non-premixed swirled natural gas flames. International Journal of Hydrogen Energy. 2006;31:669-77.

[49] Fanhua Ma NN, Mingyue Wang, Long Jiang, Renzhe Chen and Shuli Zhao. Hydrogen-enriched compressed natural gas as a fuel for engines. 2010.

[50] Heck T. Gas-Kraftwerke, Gas-Feuerungen und Wärme-Kraft-Kopplung. 20. Diskussionsforum Ökobilanzen, 19. September, ETH Zürich. Session „Energiesysteme, nicht-erneuerbar“. 2003.

[51] Timofte A. A Life Cycle Assessment of the Climeworks Technology for Direct Air Capture of Carbon Dioxide, A Semester Project in the Ecological Systems Design Group. Institute of Environmental Engineering of ETH Zurich2013.

[52] Hausschild M, Goedkoop M, Guinee J, Heijungs R, Huijbregts M, Jolliet O, et al. Recommendations for Life Cycle Impact Assessment in the European context - based on existing environmental impact assessment models and factors (International Reference Life Cycle Data System - ILCD handbook). First Edition ed: European Commission-Joint Research Centre - Institute for Environment and Sustainability; 2011.

[53] Gahleitner G. Hydrogen from renewable electricity: An international review of power-to-gas pilot plants for stationary applications. International Journal of Hydrogen Energy. 2013;38:2039-61.

[54] Bhandari R, Trudewind CA, Zapp P. Life cycle assessment of hydrogen production via electrolysis-a review. Journal of cleaner production. 2014;85:151-63.

[55] Bertuccioli L, Chan A, Hart D, Lehner F, Madden B, Standen E. Study on development of water electrolysis in the European Union. E4tech Sàrl with Element Energy Ltd for the Fuel Cells and Hydrogen Joint Undertaking; 2014.

[56] Dincer I, Acar C. Review and evaluation of hydrogen production methods for better sustainability. International Journal of Hydrogen Energy. 2015.

[57] Wokaun A, Wilhelm Ee, Schenler W, Simons A, Bauer C, Bond S, et al. Transition to Hydrogen Pathways toward clean transportation. New York: Cambridge University Press; 2011.

[58] Uusitalo V, Väisänen S, Inkeri E, Soukka R. Potential for greenhouse gas emission reductions using surplus electricity in hydrogen, methane and methanol production via electrolysis. Energy Conversion and Management. 2017;134:125-34.

[59] Burkhardt J, Patyk A, Tanguy P, Retzke C. Hydrogen mobility from wind energy - A life cycle assessment focusing on the fuel supply. Applied Energy. 2016;181:54-64.

[60] Parra D, Patel MK. Effect of tariffs on the performance and economic benefits of PV-coupled battery systems. Applied Energy. 2016;164:175-87.

[61] Parra D, Walker GS, Gillott M. Modeling of PV generation, battery and hydrogen storage to investigate the benefits of energy storage for single dwelling. Sustainable Cities and Society. 2014;10:110.

[62] Marangio F, Santarelli M, Calì M. Theoretical model and experimental analysis of a high pressure PEM water electrolyser for hydrogen production. International Journal of Hydrogen Energy. 2009;34:1143-58.

[63] Schiller M, Anderson E. Five consideratins for large-scale hydrogen electrolyzer development. Gas for Energy2014.

[64] Smolinka T, Garche J, Hebling C, Ehret O. Overview on water electrolysis for hydrogen production and storage. Symposium e Water Electrolysis and Hydrogen as Part of the Future Renewable Energy System Copenhagen, Denmark2012.

[65] Bhandari R, Clemens T, Zapp P. Life Cycle Assessment of Hydrogen Production via Electrolysis - A Review. Institute of Energy and Climate Research - Systems Analysis and Technology Evaluation (IEK STE), D - 52425 Jülich, Germany; 2013. 
[66] Pino FJ, Valverde L, Rosa F. Influence of wind turbine power curve and electrolyzer operating temperature on hydrogen production in wind-hydrogen systems. Journal of Power Sources. 2011;196:4418-26.

[67] Hawkes A, Staffell I, Brett D, Brandon N. Fuel cells for micro-combined heat and power generation. Energy \& Environmental Science. 2009;2:729-44.

[68] [online] SSTA. http://www.sma.de/en/products/battery-inverters.html.

[69] Grond L, Schulze P, Holstein J. Systems Analyses Power to Gas Deliverable 1: Technology Review. Part of TKI project TKIG01038 - Systems analyses Power-to-Gas pathways. Groningen: DNV KEMA Energy \& Sustainability; 2013.

[70] Barbir F. PEM electrolysis for production of hydrogen from renewable energy sources. Solar Energy. 2005;78:661-9.

[71] Hausschild M, Goedkoop M, Guinee J, Heijungs R, Huijbregts M, Jolliet O, et al. Recommendations for Life Cycle Impact Assessment in the European context - based on existing environmental impact assessment models and factors (International Reference Life Cycle Data System - ILCD handbook). First Edition ed: European Commission-Joint Research Centre - Institute for Environment and Sustainability; 2011.

[72] IPCC TIPoCC. Climate Change 2007: The Physical Science Basis. Contribution of Working Group I to the Fourth Assessment Report of the Intergovernmental Panel on Climate Change: Cambridge University Press, Cambridge, United Kingdom and New York, NY, USA; 2007.

[73] World Meteorological Organization W. Scientific Assessment of Ozone Depletion: 1998. Global Ozone Research and Monitoring Project. 1999.

[74] Rosenbaum RK, Bachmann TM, Gold LS, Huijbregts MAJ, Jolliet O, Juraske R, et al. USEtox-the UNEP-SETAC toxicity model: recommended characterisation factors for human toxicity and freshwater ecotoxicity in life cycle impact assessment. Int J Life Cycle Assess. 2008;13:532-46.

[75] Rabl AaS, J.V. The RiskPoll software, version 1.0551 (dated August 2004). 2004.

[76] Greco SL, Wilson AM, Spengler JD, Levy JI. Spatial patterns of mobile source particulate matter emissions-to-exposure relationships across the United States. Atmospheric Environment. 2007;41:101125.

[77] Frischknecht R, Braunschweig A, Hofstetter P, Suter P. Human health damages due to ionising radiation in life cycle impact assessment. Environmental Impact Assessment Review. 2000;20:159-89. [78] Dreicer M, Tort, V., Manen, P. . ExternE, Externalities of Energy, Vol. 5 Nuclear. In: European Commission DGXII S, Research and Development JOULE, Luxembourg., editor.: Centr d'étude sur l'Evaluation de la Protection dans le domaine nucléaire (CEPN); 1995.

[79] Garnier-Laplace J. C. B-SK, Gilbin R, Della-Vedova C, Jolliet O, Payet J. A Screening Level Ecological Risk Assessment and ranking method for liquid radioactive and chemical mixtures released by nuclear facilities under normal operating conditions. International conference on radioecology and environmental protection. Bergen2008.

[80] van Zelm R, Huijbregts MAJ, den Hollander HA, van Jaarsveld HA, Sauter FJ, Struijs J, et al. European characterization factors for human health damage of PM10 and ozone in life cycle impact assessment. Atmospheric Environment. 2008;42:441-53.

[81] Seppälä J, Posch M, Johansson M, Hettelingh J-P. Country-dependent Characterisation Factors for Acidification and Terrestrial Eutrophication Based on Accumulated Exceedance as an Impact Category Indicator (14 pp). Int J Life Cycle Assess. 2006;11:403-16.

[82] Posch M, Seppälä J, Hettelingh J-P, Johansson M, Margni M, Jolliet O. The role of atmospheric dispersion models and ecosystem sensitivity in the determination of characterisation factors for acidifying and eutrophying emissions in LCIA. Int J Life Cycle Assess. 2008;13:477-86.

[83] Struijs J, Beusen, A., van Jaarsveld, H. and Huijbregts, M.A.J. . Chapter 6, Aquatic Eutrophication In: Goedkoop M, Heijungs, R., Huijbregts, M.A.J., De Schryver, A., Struijs, J., Van Zelm, R. , editor. ReCiPe 
2008 A life cycle impact assessment method which comprises harmonised category indicators at the midpoint and the endpoint level Report I: Characterisation factors, first edition2009.

[84] Milà i Canals L, Chenoweth J, Chapagain A, Orr S, Antón A, Clift R. Assessing freshwater use impacts in LCA: Part I-inventory modelling and characterisation factors for the main impact pathways. Int J Life Cycle Assess. 2009;14:28-42.

[85] Frischknecht R, Steiner, R., Jungbluth, N. . Methode der ökologischen Knappheit - Ökofaktoren 2006. ö.b.u. und Bundesamt für Umwelt, Bern; 2008. 